Prepared in cooperation with the Wind River Environmental Quality Commission

\title{
Monitoring-Well Network and Sampling Design for Ground- Water Quality, Wind River Indian Reservation, Wyoming
}

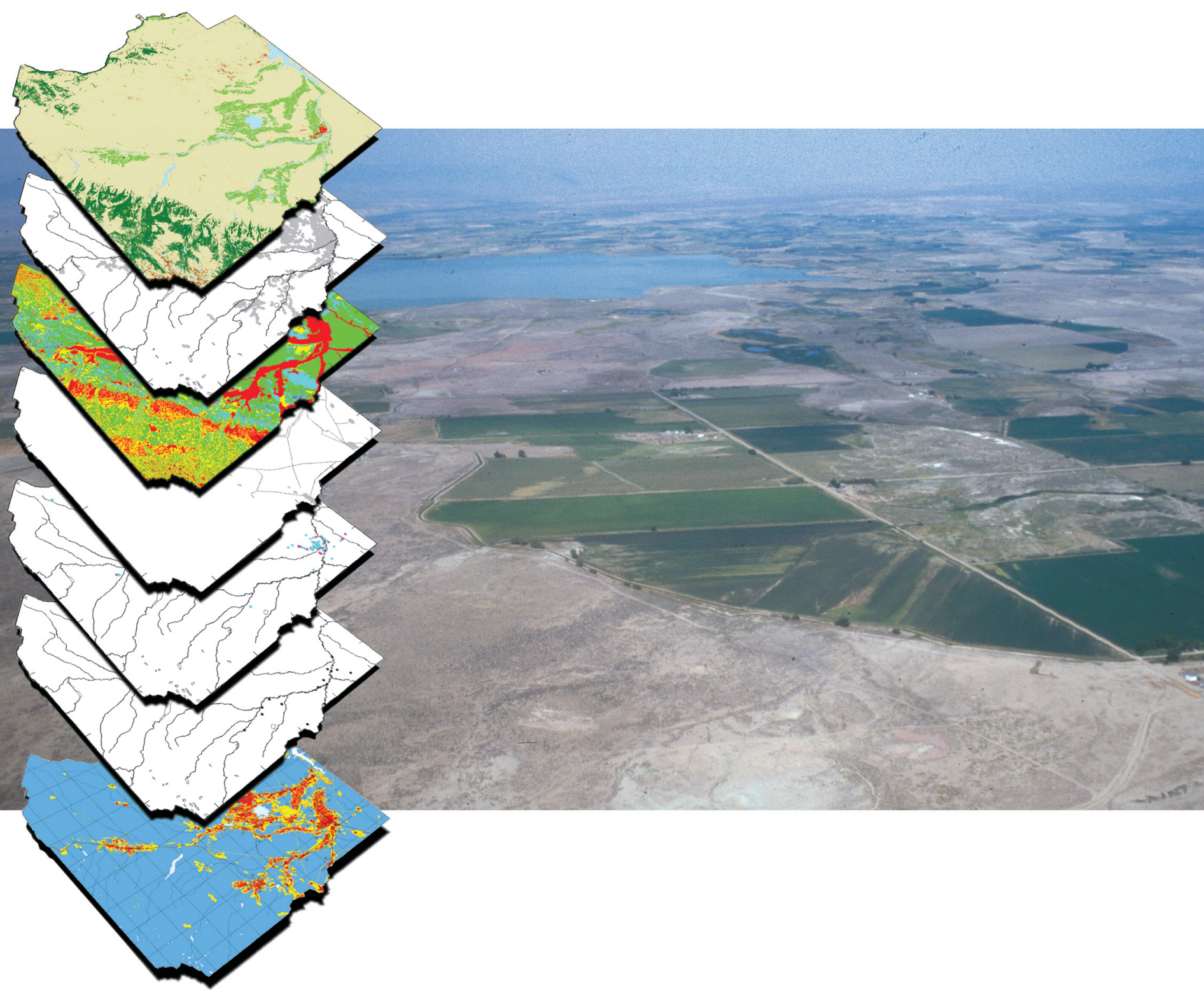

Scientific Investigations Report 2005-5027 


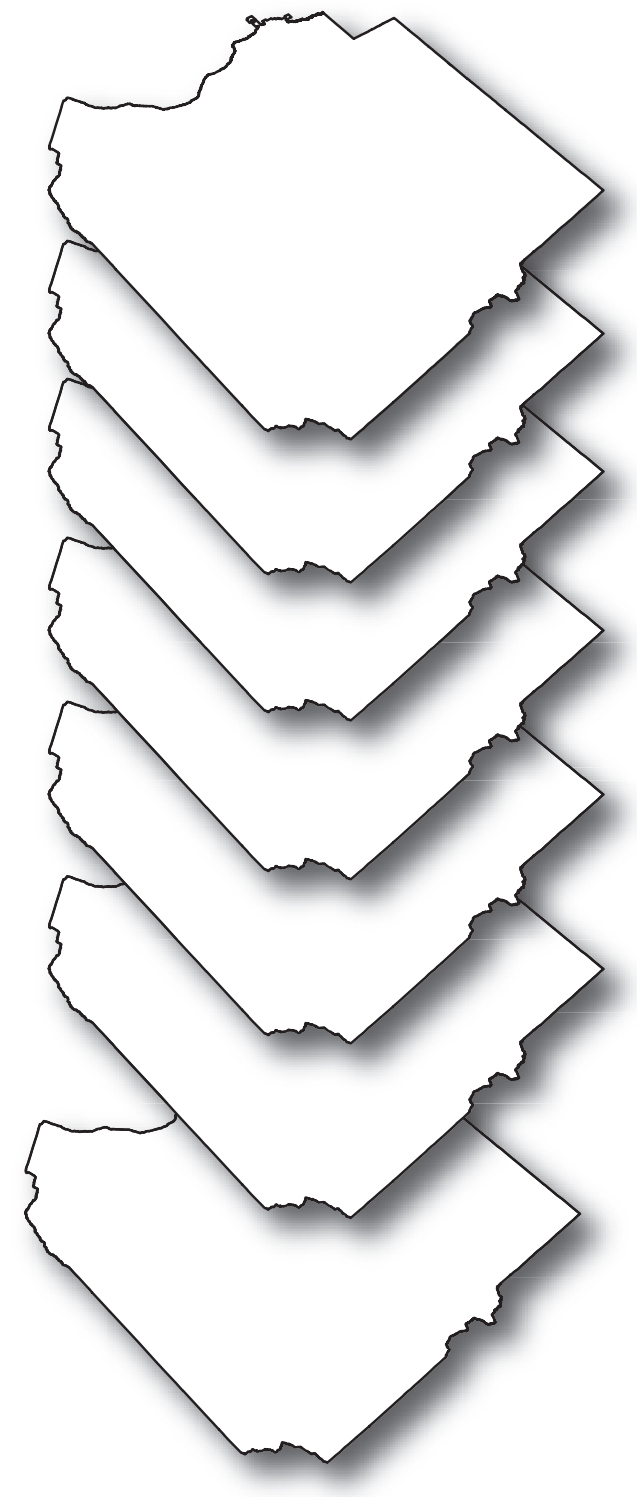

ON THE COVER: Geographic Information System data layers (from top to bottom); National Land Cover Dataset, water well density, aquifer sensitivity, oil and natural gas fields and petroleum pipelines, sites with potential contaminant sources, sites that are known to have ground-water contamination, National Pollutant Discharge Elimination System sites, and a prioritization map for monitoring ground-water quality on the Reservation. Background photograph is an aerial view of Ocean Lake by Jon P. Mason, U.S. Geological Survey. The surrounding irrigated areas are part of the Riverton Reclamation Project. 


\section{Monitoring-Well Network and Sampling Design for Ground-Water Quality, Wind River Indian Reservation, Wyoming}

By Jon P. Mason, Sonja K. Sebree, and Thomas L. Quinn

Prepared in cooperation with the

Wind River Environmental Quality Commission

Scientific Investigations Report 2005-5027

U.S. Department of the Interior

U.S. Geological Survey 


\section{U.S. Department of the Interior \\ Gale A. Norton, Secretary \\ U.S. Geological Survey \\ Charles G. Groat, Director}

U.S. Geological Survey, Reston, Virginia: 2005

For sale by U.S. Geological Survey, Information Services
Box 25286, Denver Federal Center
Denver, CO 80225
For more information about the USGS and its products:
Telephone: 1-888-ASK-USGS
World Wide Web: http://www.usgs.gov/

Any use of trade, product, or firm names in this publication is for descriptive purposes only and does not imply endorsement by the U.S. Government.

Although this report is in the public domain, permission must be secured from the individual copyright owners to reproduce any copyrighted materials contained within this report. 


\section{Contents}

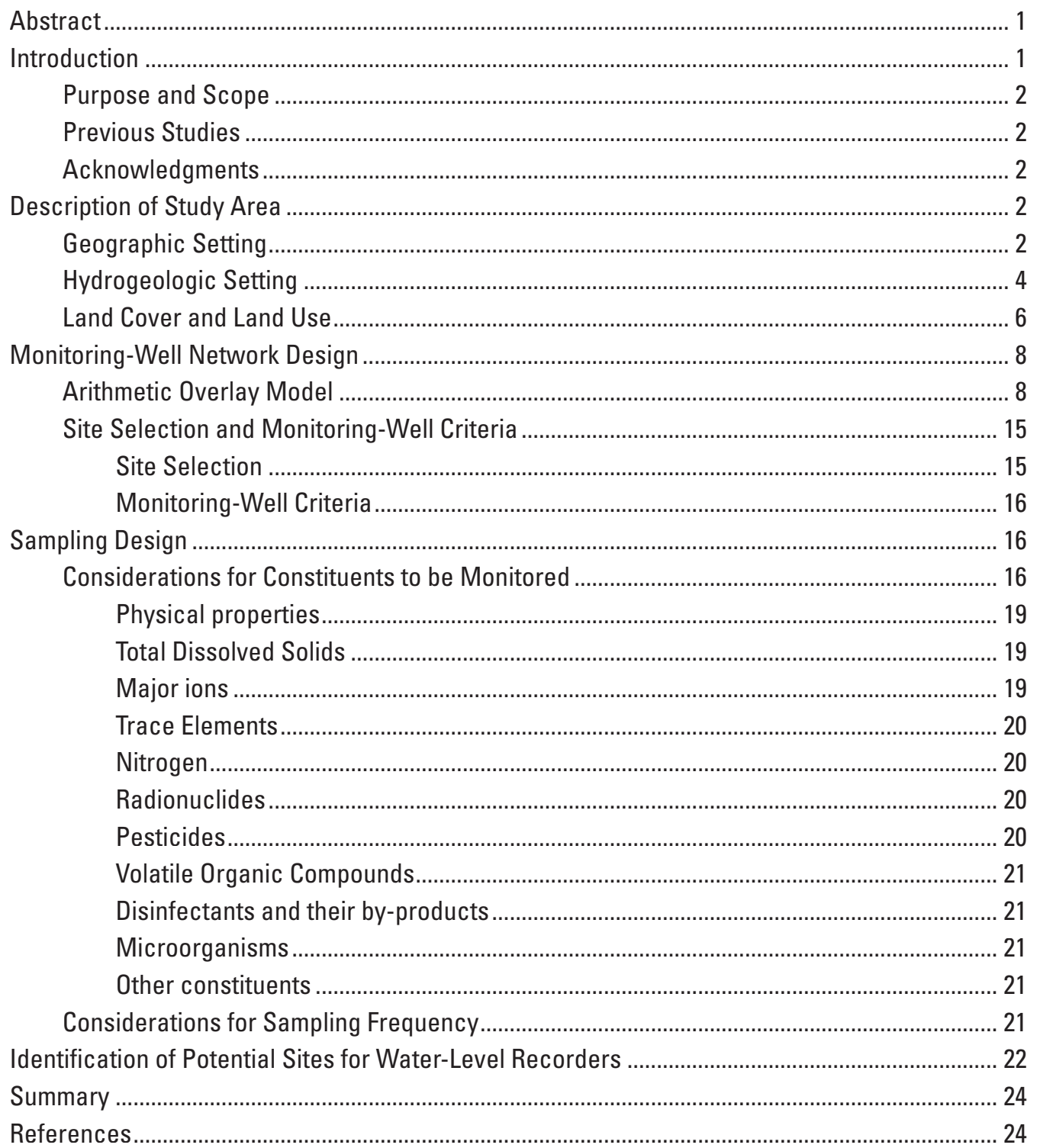

Appendix 1. Point rating scheme for arithmetic overlay model used to create the groundwater-quality-monitoring prioritization map on the Wind River Indian Reservation, Wyoming

Appendix 2. U.S. Environmental Protection Agency Maximum Contaminant Levels (MCLs) for drinking water

Appendix 3. U.S. Environmental Protection Agency Secondary Maximum Contaminant Levels (SMCLs) for drinking water ...................................................................................... 38

Appendix 4. State of Wyoming ground-water-quality standards ................................................... 38 


\section{Figures}

1. Map showing location of physiographic features in and near the Wind River Indian Reservation, Wyoming.

2. Stratigraphic section and hydrologic roles of rocks on the Wind River Indian Reservation, Wyoming.

3-10. Maps showing:

3. Land cover and land use on the Wind River Indian Reservation, Wyoming. 7

4. Land-cover and land-use categories on the Wind River Indian Reservation, Wyoming

5. Irrigation areas on the Wind River Indian Reservation, Wyoming....

6. Water-well density layer used in arithmetic overlay model, Wind River Indian Reservation, Wyoming.

7. Aquifer sensitivity to surface contamination on the Wind River Indian Reservation, Wyoming

8. Oil and gas fields and petroleum pipelines on the Wind River Indian Reservation, Wyoming

9. Sites with potential ground-water contaminant sources and sites with known ground-water contamination on the Wind River Indian Reservation, Wyoming

10. National Pollutant Discharge Elimination System sites on the Wind River Indian Reservation, Wyoming.

11. Diagram of arithmetic overlay model used to create prioritization map for monitoring ground-water quality on the Wind River Indian Reservation, Wyoming..... 17

12. Map showing high-priority areas for ground-water-quality monitoring on the Wind River Indian Reservation, Wyoming, divided into 30 equal areas

\section{Plate}

1. Map showing prioritized areas for ground-water-quality monitoring on the Wind River Indian Reservation, Wyoming in pocket

\section{Tables}

1. Inventory of ground-water wells and their use on the Wind River Indian Reservation, Wyoming....

2. Sampling schedule designed for a 30 -well ground-water-quality monitoring network on the Wind River Indian Reservation, Wyoming 


\section{Conversion Factors and Datums}

\begin{tabular}{|c|c|c|}
\hline Multiply & By & To obtain \\
\hline \multicolumn{3}{|c|}{ Length } \\
\hline foot $(\mathrm{ft})$ & 0.3048 & meter $(\mathrm{m})$ \\
\hline mile (mi) & 1.609 & kilometer $(\mathrm{km})$ \\
\hline \multicolumn{3}{|c|}{ Area } \\
\hline acre & 4,047 & square meter $\left(\mathrm{m}^{2}\right)$ \\
\hline section (640 acres or 1 square mile) & 259.0 & square hectometer $\left(\mathrm{hm}^{2}\right)$ \\
\hline square mile $\left(\mathrm{mi}^{2}\right)$ & 2.590 & square kilometer $\left(\mathrm{km}^{2}\right)$ \\
\hline \multicolumn{3}{|c|}{ Flow rate } \\
\hline gallon per minute (gal/min) & 0.06309 & liter per second $(\mathrm{L} / \mathrm{s})$ \\
\hline
\end{tabular}

Horizontal coordinate information is referenced to the North American Datum of 1983 (NAD 83).

Vertical coordinate information is referenced to the National Geodetic Vertical Datum of 1929 (NGVD 29).

Altitude, as used in this report, refers to distance above the vertical datum.

\section{Abbreviations used in this report}

$\begin{array}{ll}\text { ASTM } & \text { American Society for Testing and Materials } \\ \text { GIS } & \text { geographical information system } \\ \text { HPC } & \text { heterotrophic plate count } \\ \text { MCL } & \text { Maximum Contaminant Level } \\ \text { MFL } & \text { million fibers per liter } \\ \text { MRDL } & \text { maximum residual disinfectant level } \\ \text { mg/L } & \text { milligrams per liter } \\ \text { MTBE } & \text { methyl tert-butyl ether } \\ \text { NAWQA } & \text { National Water-Quality Assessment Program } \\ \text { NLCD } & \text { National Land Cover Dataset } \\ \text { NPDES } & \text { National Pollutant Discharge Elimination System } \\ \text { NTU } & \text { nephelometric turbidity units } \\ \text { PVC } & \text { polyvinyl chloride } \\ \text { SMCL } & \text { Secondary Maximum Contaminant Level } \\ \text { STATSGO } & \text { State Soil Geographic Data Base } \\ \text { TDS } & \text { total dissolved solids } \\ \text { TT } & \text { treatment technique } \\ \text { USEPA } & \text { U.S. Environmental Protection Agency } \\ \text { USGS } & \text { U.S. Geological Survey } \\ \text { VOC } & \text { volatile organic compound } \\ \text { WREOC } & \text { Wind River Environmental Quality Commission } \\ \text { WRFIP } & \text { Wind River Federal Irrigation Project } \\ & \end{array}$





\title{
Monitoring-Well Network and Sampling Design for Ground-Water Quality, Wind River Indian Reservation, Wyoming
}

\author{
By Jon P. Mason, Sonja K. Sebree, and Thomas L. Quinn
}

\section{Abstract}

The Wind River Indian Reservation, located in parts of Fremont and Hot Springs Counties, Wyoming, has a total land area of more than 3,500 square miles. Ground water on the Wind River Indian Reservation is a valuable resource for Shoshone and Northern Arapahoe tribal members and others who live on the Reservation. There are many types of land uses on the Reservation that have the potential to affect the quality of ground-water resources. Urban areas, rural housing developments, agricultural lands, landfills, oil and natural gas fields, mining, and pipeline utility corridors all have the potential to affect ground-water quality. A cooperative study was developed between the U.S. Geological Survey and the Wind River Environmental Quality Commission to identify areas of the Reservation that have the highest potential for ground-water contamination and develop a comprehensive plan to monitor these areas.

An arithmetic overlay model for the Wind River Indian Reservation was created using seven geographic information system data layers representing factors with varying potential to affect ground-water quality. The data layers used were: the National Land Cover Dataset, water well density, aquifer sensitivity, oil and natural gas fields and petroleum pipelines, sites with potential contaminant sources, sites that are known to have ground-water contamination, and National Pollutant Discharge Elimination System sites. A prioritization map for monitoring ground-water quality on the Reservation was created using the model. The prioritization map ranks the priority for monitoring ground-water quality in different areas of the Reservation as low, medium, or high. To help minimize bias in selecting sites for a monitoring well network, an automated stratified random site-selection approach was used to select 30 sites for ground-water quality monitoring within the high priority areas. In addition, the study also provided a sampling design for constituents to be monitored, sampling frequency, and a simple water-table level observation well network.

\section{Introduction}

Ground water on the Wind River Indian Reservation, Wyoming, hereinafter also referred to as the Reservation, is a valuable resource for the Shoshone and Northern Arapahoe tribal members and others who live on the Reservation. In addition to being the major source of water for the rural population on the Reservation, ground water also is used for municipal, industrial, commercial, mining, livestock, and irrigation uses (U.S. Geological Survey, 2001).

The Wind River Environmental Quality Commission (WREQC) is charged with maintaining the integrity of the environmental resources of the Reservation. This mission includes the inventory, assessment, and protection of the ground-water resources on the Reservation.

Because ground water is such an important resource for the Reservation, the WREQC needs a strategy that protects and allows for the continued use of the resource in a sustainable manner. Many types of land use occur on the Reservation that have the potential to affect the quality of ground-water resources. Urban areas, rural housing developments, agricultural lands, landfills, oil and natural gas fields, mining, and pipeline utility corridors, all have the potential to affect ground-water quality. Because of the interaction between ground water and surface water, activities that affect surfacewater quality (urban runoff, sewage disposal, agricultural return flows) also have the potential to affect ground-water quality. Additionally, activities that occur in the subsurface (such as waste disposal through underground injection) could affect ground-water quality. The effects of various activities on ground-water resources are complicated by site-specific hydrogeology. Some aquifers are more sensitive to potential contaminant sources than others, depending on their hydrogeological characteristics and proximity to potential source(s). There are additional complications related to natural sources of constituents in the ground water, such as elevated concentrations of trace elements and the presence of radioisotopes. 
To effectively protect, manage, and ensure continued use of ground-water resources, a ground-water-quality monitoring network is needed that considers land-use activities, hydrogeological characteristics, and ground-water resources as a system. A network of this type will facilitate management of ground-water resources by providing an assessment of the resources in relation to multiple land uses and their effects on water quality, identification of areas for continued monitoring to establish trends or changes in water quality, and water-level monitoring over time.

Protection of ground-water resources is necessary for the continued economic success and quality of life on the Reservation. Providing adequate ground-water monitoring on the Reservation is made difficult by the large area (3,500 miles squared $\left.\left(\mathrm{mi}^{2}\right)\right)$ to monitor. For this reason, it is important to focus limited resources on monitoring areas that are the most vulnerable to potential ground-water contamination. The U.S. Geological Survey (USGS), in cooperation with the WREQC, conducted a study to identify areas of the Reservation that have the highest potential for ground-water contamination and to develop a comprehensive plan to monitor these areas.

\section{Purpose and Scope}

The purpose of this report is to describe the monitoringwell network and sampling design for ground-water quality on the Wind River Indian Reservation. The monitoring-well network design includes the application of an arithmetic overlay model to determine high-priority areas within the Reservation for monitoring ground-water quality, application of a stratified-random approach for site selection, and criteria for selecting monitoring wells. The sampling design includes considerations for selecting constituents for monitoring and sampling frequency. In addition, potential sites to install waterlevel recorders were assessed.

\section{Previous Studies}

Many studies involving ground-water resources have been completed on the Reservation. Daddow (1996, p. 4-5) provides an overview of water-resources studies conducted on the Reservation prior to 1995 . Only a few studies that include ground-water resources have been completed since 1995. Eddy-Miller and Norris (2000) discuss the results from ground-water sampling in 1998 and 1999 for pesticides in Fremont County, Wyoming. A report by Zelt and others (1999) includes a brief summary of ground-water resources for the Wind River Basin.

\section{Acknowledgments}

The authors gratefully acknowledge Laura Hallberg of the U.S. Geological Survey for creating the water well and ground-water quality database used in this study. Jodi Nor- ris and Robert Kirkwood of the U.S. Geological Survey are acknowledged for their contributions to the geographical information system used in this study. Sue Roberts of the U.S. Geological Survey is acknowledged for her skillful preparation of the report figures and text. Reviews by Virginia McGuire, Jason Masoner, Janet Carter, and Keith Lucey of the U.S. Geological Survey improved the quality of the report.

\section{Description of Study Area}

The Wind River Indian Reservation, located in westcentral Wyoming, was created in 1863 with the signing of the first Fort Bridger Treaty. Since its establishment the Reservation boundaries have changed many times. The largest change occurred in 1868 with the signing of the second Fort Bridger Treaty. This treaty reduced the Reservation size from nearly $70,000 \mathrm{mi}^{2}$ to about $4,300 \mathrm{mi}^{2}$. In 1874 , another $780 \mathrm{mi}^{2}$ were removed from the Reservation to allow for gold mining in the South Pass area (U.S. Department of Commerce, Economic Development Administration, 2004). Today the Reservation includes slightly more than 3,500 $\mathrm{mi}^{2}$ located in Fremont and Hot Springs Counties (fig. 1). The total Reservation population is 23,245 (U.S. Census Bureau, 2004) of which about 7,300 people are Shoshone and Northern Arapahoe tribal members (U.S. Department of Commerce, Economic Development Administration, 2004).

\section{Geographic Setting}

The Reservation is located in the Wyoming Basin Physiographic Province of the Rocky Mountain Region (Raisz, 1972, p. 30). Most of the Reservation lies in the western one-half of the Wind River Structural Basin, a large structural basin with a total area of about 8,500 $\mathrm{mi}^{2}$ (Keefer and Van Lieu, 1966, p. B2). The structural basin shares its name with the Wind River Range, which forms the southwestern boundary of the basin. The northwestern boundary of the structural basin consists of the Absaroka and Washakie Ranges. The Owl Creek Mountains, Bighorn Mountains, and Casper Arch make up the northern and northeastern boundaries of the structural basin, and the southern boundary consists of the Granite Mountains. The northeastern part of the Reservation extends north over the Owl Creek Mountains and into the southern end of the Bighorn Basin (fig. 1).

Physiography of the Reservation includes areas of mountainous alpine glaciated terrain, foothills, high plateaus, rugged badlands, plains, and terraced stream valleys (Daddow, 1996, p. 7). Land-surface altitudes range from about 4,400 feet (ft) above the National Geodetic Vertical Datum of 1929 (NGVD 29) near the northeastern boundary of the Reservation to more than 12,000 ft above NGVD 29 in the Wind River Range at the southwestern boundary. Altitudes in the central part of the Reservation range mainly between 4,800 and 6,000 ft (Daddow, 1996, p. 7). 


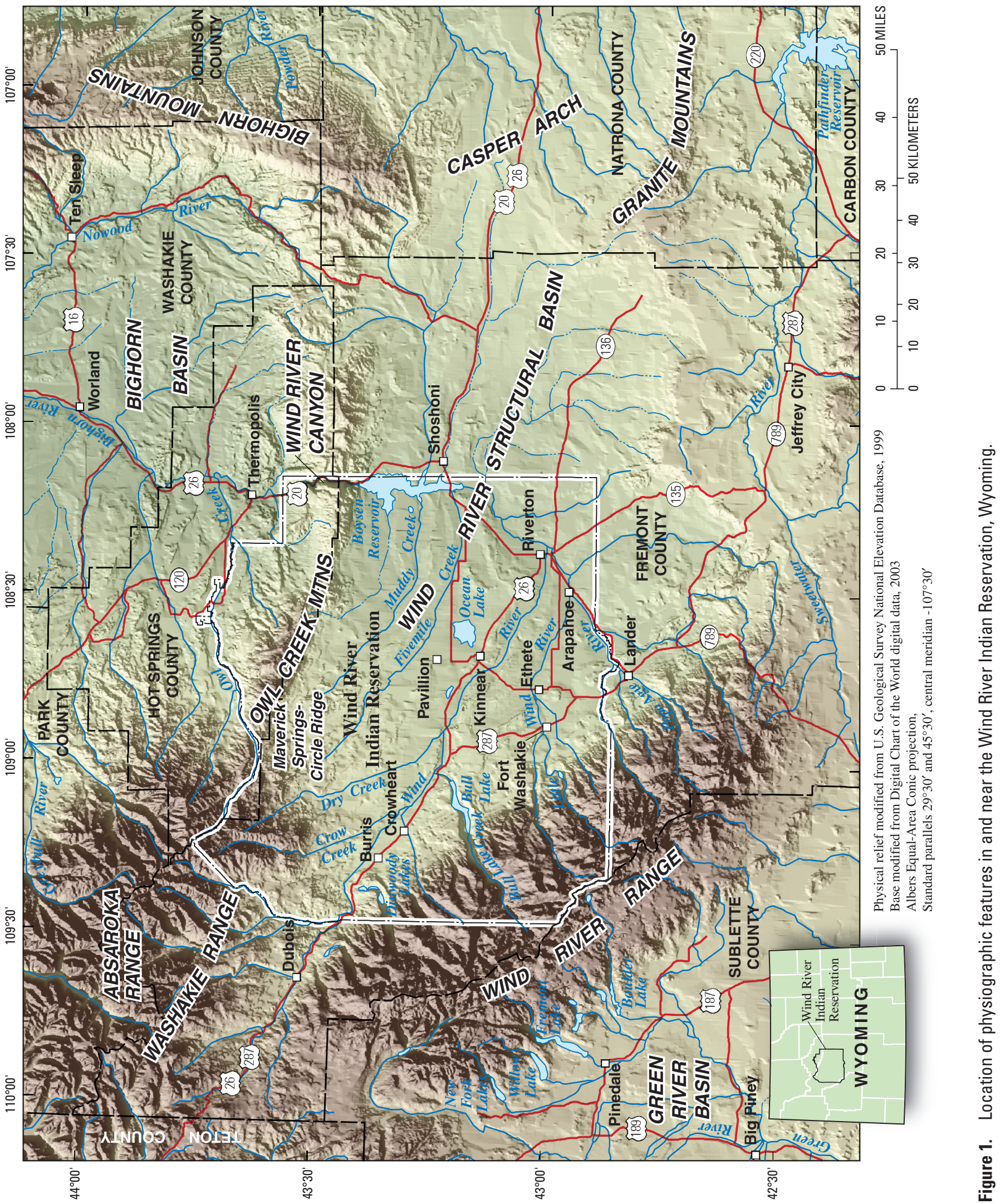


The Wind River, which originates in mountains west of the Reservation, is the major drainage system on the Reservation. It flows to the southeast towards Riverton where it is joined by the Little Wind River. At the confluence with the Little Wind River, it turns north and eventually flows through Wind River Canyon and into the Bighorn Basin where it is called the Bighorn River. Major tributaries to the Wind River on the Reservation are Bull Lake Creek, Little Wind River, Popo Agie River, Crow Creek, Dry Creek, Fivemile Creek, and Muddy Creek (fig. 1).

\section{Hydrogeologic Setting}

The following is a brief overview of the Reservation's hydrogeologic setting; for a more detailed description the reader is referred to Keefer (1965), McGreevy and others (1969), Keefer and Van Lieu (1966), Richter (1981), Daddow (1996), and Johnson and others (1996). Richter (1981) divided the geologic units of the Wind River Structural Basin into hydrostratigraphic units, or hydrologic role, which were the basis for figure 2. Figure 2 was modified from Richter (1981) to better reflect the hydrostratigraphy specific to the Reservation. The hydrostratigraphy on the Reservation can be divided into local Quaternary aquifers, 10 bedrock aquifers, one aquifer system, and 11 confining layers.

Early estimates on the total thickness of sedimentary rocks on the Reservation were as much as 40,000 ft (McGreevy and others, 1969, p. I12). A more recent estimate of about 25,000 ft was made by Blackstone (1993). A well drilled in section 26, Township 5 North, Range 3 East, penetrated $24,818 \mathrm{ft}$ of sedimentary rock before stopping in the Triassic-age Popo Agie Formation, the uppermost formation in the Chugwater Group. It is likely that the top of the Precambrian rocks was at least 2,000 ft below the bottom of this well, based on known thicknesses of the Chugwater Group and the underlying Paleozoic formations. Rocks from all geologic periods except the Silurian are present on the Reservation.

Quaternary deposits on the Reservation include alluvium, colluvium, eolian, terrace, pediment, landslide, glacial, and travertine (McGreevy and others, 1969, p. I13). The maximum thickness of these deposits is probably around $200 \mathrm{ft}$ (Richter, 1981, p. 87), but generally these deposits are less than $50 \mathrm{ft}$ thick. Daddow (1996, p. 16 and 46-52) reported that water yields from wells in Quaternary aquifers on the Reservation ranged from 2 to 60 gallons per minute (gal/min), and dissolved-solids concentrations ranged from 109 to 4,630 milligrams per liter $(\mathrm{mg} / \mathrm{L})$. Alluvial aquifers along the Wind, Little Wind, and Popo Agie Rivers generally had lower dissolved solids than alluvial aquifers along ephemeral or intermittent streams and Owl Creek.

The Tertiary Wind River and Fort Union Formations are the thickest sedimentary formations on the Reservation. In the basin trough, their combined thickness is greater than $10,000 \mathrm{ft}$. This great thickness is the result of the Laramide orogenic event in the Late Cretaceous Period that caused earlier sedimentary deposits to be eroded around the margin of the Wind River Structural Basin and deposited towards its center. For this reason, the lithology and thickness of these two formations vary greatly in different parts of the Reservation. The Wind River Formation is exposed in much of the central and eastern parts of the Reservation, where it is an important aquifer. The Indian Meadows Formation lies between the Wind River and Fort Union Formations, but it is not differentiated in the subsurface of the Wind River Structural Basin. Daddow (1996, p. 20 and 52) reported that water yields from wells in the Wind River aquifer ranged from 0.1 to $350 \mathrm{gal} / \mathrm{min}$, and dissolved-solids concentrations ranged from 211 to $5,110 \mathrm{mg} / \mathrm{L}$; these large ranges result in part from the varied lithology of the formation. In the northwestern corner of the Reservation, Tertiary volcaniclastic rocks of the Wiggins, Tepee Trail, and Aycross Formations occur. Although no wells were completed in these volcaniclastic rocks, waterquality samples collected from three springs discharging from volcaniclastic rocks had dissolved-solids concentrations ranging from 197 to $244 \mathrm{mg} / \mathrm{L}$ (Daddow, 1996). Discharges from the springs ranged from 8 to $37 \mathrm{gal} / \mathrm{min}$. It is likely that most of the water samples from Tertiary aquifers evaluated by Daddow (1996) came from relatively shallow depths (less than 1,000 ft). At depths of greater than a few thousand feet it is likely that the water from Tertiary aquifers is highly saline (dissolved-solids concentrations between 10,000 and $35,000 \mathrm{mg} / \mathrm{L}$ ) to briny (dissolved-solids concentrations greater than $35,000 \mathrm{mg} / \mathrm{L})$.

Mesozoic rocks on the Reservation were deposited during a period of repeated transgressions and regressions of an epicontinental sea (Keefer, 1970, p. D8). The rocks consist mostly of siltstone, sandstone, and shale. Smaller amounts of claystone, conglomerate, coal, bentonite, limestone, dolomite, and gypsum also are present. These rocks are overlain by thick Tertiary deposits, except near the flanks of the mountains and around some of the structures in the basin such as in the Maverick Springs-Circle Ridge area (McGreevy and others, 1969, p. I40). Daddow (1996, p. 20) reported that water yields from wells in Mesozoic aquifers ranged from 0.5 to $90 \mathrm{gal} / \mathrm{min}$, and dissolved-solids concentrations ranged from 182 to $6,060 \mathrm{mg} / \mathrm{L}$. In general, the median values for dissolved-solids concentrations in the water samples from Mesozoic aquifers were about 1,000 mg/L, except in water samples from the Cody Shale, which had a median value of $2,540 \mathrm{mg} / \mathrm{L}$. It is likely that most of the water samples from Mesozoic aquifers evaluated by Daddow (1996) came from relatively shallow depths near recharge areas. Away from these areas, water from Mesozoic aquifers probably is saline to briny. Daddow (1996) did not evaluate water from all Mesozoic aquifers because wells or springs could not be found in some cases.

No recognizable angular discordances exist within the Paleozoic rocks in the Wind River Structural Basin, which indicates that the Paleozoic Era was a period of remarkable crustal stability in the region where the present day Wind 


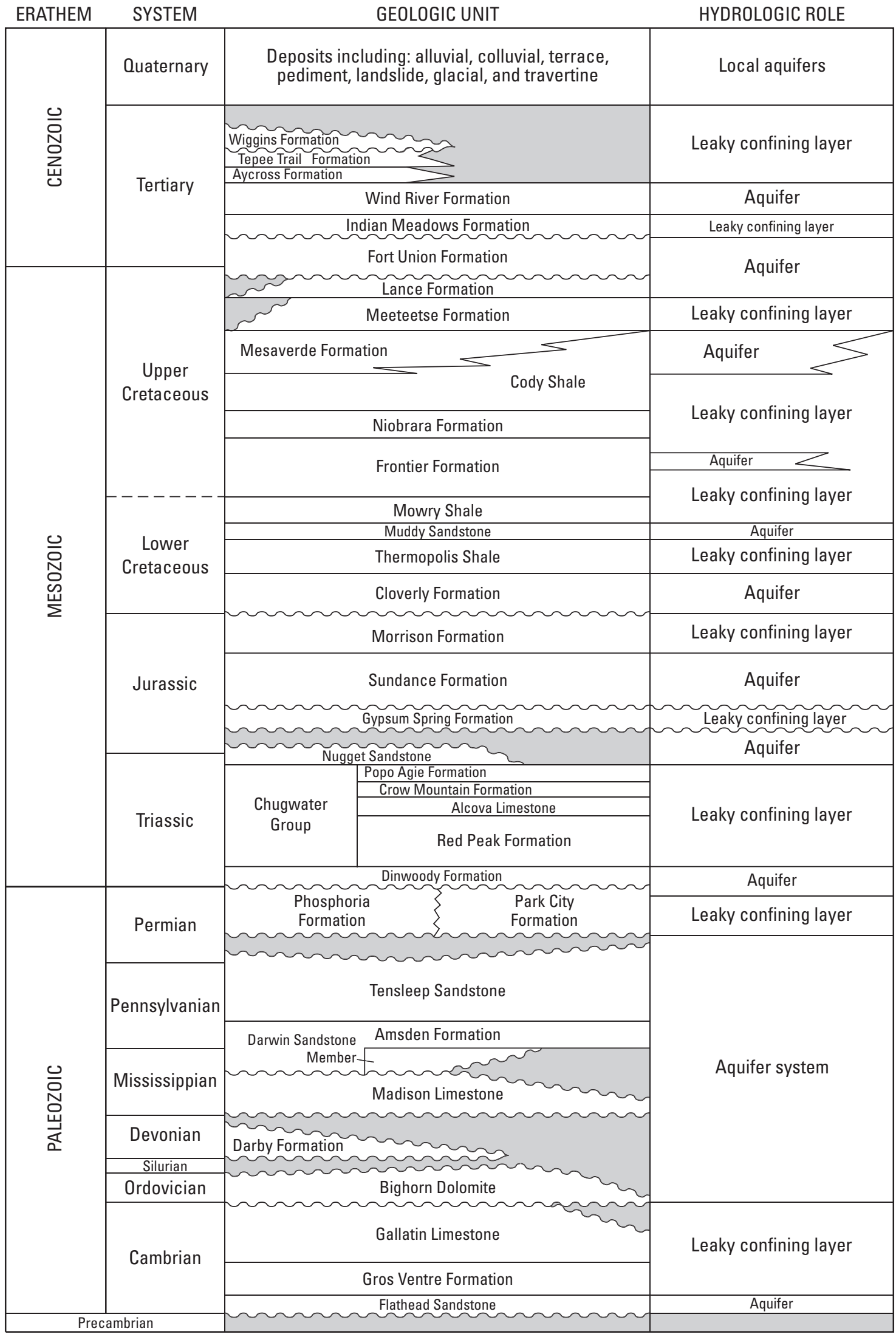

Figure 2. Stratigraphic section and hydrologic roles of rocks on the Wind River Indian Reservation, Wyoming (modified from Richter, 1981, fig. Il-6). 
River Structural Basin is located (Keefer and Van Lieu, 1966, p. B50). Like the Mesozoic strata, transgressions and regressions of an epicontinental sea occurred during the deposition of Paleozoic rocks (Keefer and Van Lieu, 1966, p. B6). The rocks are composed mostly of sandstone, shale, limestone, and dolomite, with some chert. In the Late Paleozoic Period, phosphatic beds and gypsiferous shale also were deposited. Many of these rocks are cliff-forming and are exposed in steep walled canyons on the northeast flank of the Wind River Range and in Wind River Canyon through the Owl Creek Mountains. Well-yield and water-quality records are sparse for Paleozoic aquifers. Richter (1981, p. 54-71) reported that water yields from selected wells (mainly oil and gas well tests) completed in Paleozoic rocks ranged from several tens of gallons per minute to as much as $1,500 \mathrm{gal} / \mathrm{min}$. He also reported flows of less than $10 \mathrm{gal} / \mathrm{min}$ from springs along the Owl Creek Mountains. According to Richter (1981, p. 98-105), dissolved solids in Paleozoic aquifers range from less than $500 \mathrm{mg} / \mathrm{L}$ to more than 3,000 mg/L. Most of these water-quality samples probably came from shallow depths (less than a few thousand feet). In the central basin area where these rocks are deeply buried, the dissolved-solids content is probably much greater.

Precambrian igneous and metamorphic rocks form the cores of the Wind River Range, Washakie Range, and Owl Creek Mountains on the Reservation. These rocks, which are widely exposed in the Wind River Range and in Wind River Canyon through the Owl Creek Mountains, are typically granite, granite gneiss, or schist, although locally mafic dikes are present (Keefer, 1970, p. D8). Little is known about potential yields of water to wells and water quality in Precambrian aquifers. McGreevy and others (1969, p. I38) suggested that water yields of as much as $30 \mathrm{gal} / \mathrm{min}$ may be possible where rocks are fractured or weathered. They reported that dissolved-solids concentrations of less than $200 \mathrm{mg} / \mathrm{L}$ are likely near outcrop areas.

\section{Land Cover and Land Use}

Both ground-water quality and quantity can be directly affected by land cover and land use. The areal extent of a land cover or land use determines the ground-water area it could potentially affect. The relation between intensity of land use and potential effects to ground water is less straightforward, but in general the higher the land-use intensity, the more likely that the ground water will be affected. Agricultural land use is an example of land use with broad areal extent and moderate intensity. It can affect ground-water quality through the application of pesticides and fertilizers and by irrigation practices. In addition, ground-water quantity can be affected by irrigation, evapotranspiration from crops, and changes in infiltration rates through the soil. Urban land use on the Reservation is an example of land use with small areal extent but high-intensity use. Commercial and industrial chemicals, as well as pesticides and fertilizers, typically are used in urban areas and have the potential to enter the ground water. In general, urban land use may be a greater threat to ground-water quality than agricultural land use, but the area it can affect is much smaller. Other land uses, such as rangeland and forest have broad areal extents but low-intensity use and are less likely to affect the ground water than agricultural and urban land uses. Land cover/land use for the Wind River Indian Reservation is shown in figure 3.

The National Land Cover Dataset (NLCD) was the source of land-cover and land-use data for the study described in this report (U.S. Geological Survey, 1992). The NLCD was produced by a consortium of several federal agencies, including the USGS, to provide a consistent and seamless land-cover data set for the conterminous United States. Land-cover mapping was done using early 1990s Landsat Thematic Mapper imagery with a resolution of 30 meters, augmented with other geospatial ancillary data sets. Twenty-one thematic classes resembling the land-cover/land-use classification system of Anderson and others (1976) are used in the NLCD. For simplification in this report, similar classes were combined together so that the original 21 classes were reduced to 10 categories shown in figure 4. Eight categories are shown in figure 3, because shrubland and grassland were combined into a rangeland category and pasture/hay/fallow and row crops/small grains were combined into an agriculture category.

Rangeland is the largest land use on the Reservation. About 82 percent of the total Reservation area is classified as rangeland, with nearly 60 percent of the total Reservation area covered by shrubland and about 22 percent covered by grassland (figs. 3 and 4). Although agricultural statistics are not available for the Reservation itself, statistics for Fremont County show that the total number of cattle was approximately 120,000 and the total number of breeding sheep was approximately 14,000 in 2001 (Wyoming Department of Agriculture, 2001, p. 45 and 58).

Forest and agriculture both compose about 7 percent of the land use on the Reservation (figs. 3 and 4). Because there have never been any large-scale silviculture operations or development on the Reservation's forested lands, it is assumed that anthropogenic influences to ground water in forested areas are minimal. Pasture, hay, and fallow lands combined make up about 5.5 percent of the total land use on the Reservation, whereas row crops and small grains make up about 1.6 percent of the total land-use area (figs. 3 and 4). According to county crop estimates (Wyoming Department of Agriculture, 2001, p. 76-88), hay was the dominant crop harvested during the 2000 growing season in Fremont County. Of the total acres harvested in Fremont County during the 2000 growing season, 86 percent were hay. Each of the other crops harvested during the 2000 growing season (barley, oats, dry beans, sugar beets, and corn) made up less than 6 percent of the total acres harvested. The 1987 Census of Agriculture (Battaglin and Goolsby, 1995) estimated that commercial fertilizers were applied to 60,365 acres in Fremont County, or slightly more than 1 percent of the total county area, and pesticides were 


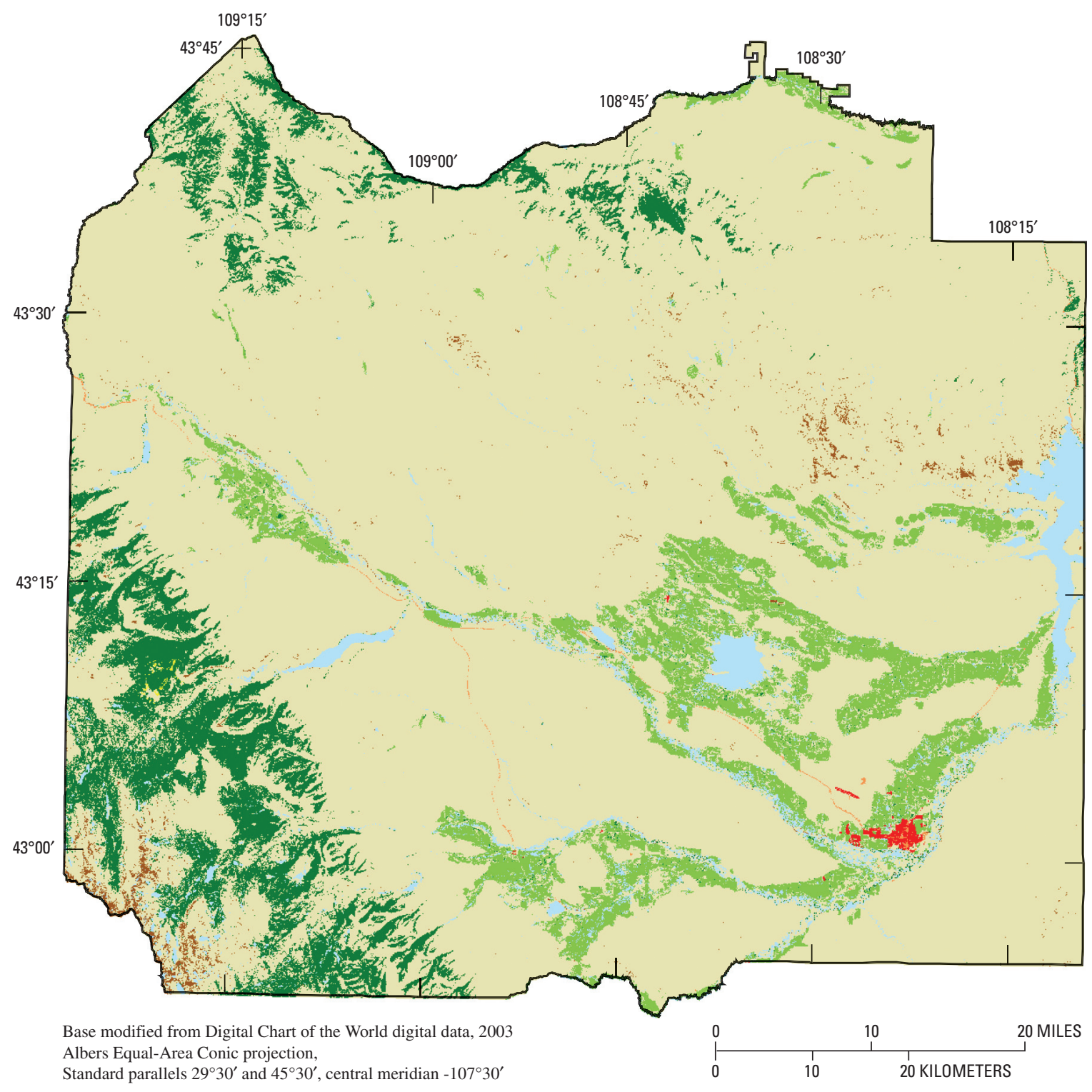

EXPLANATION

Land-cover/land-use category

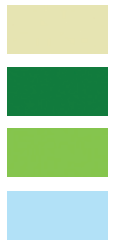

Rangeland
Forest
Agriculture
Open water/perennial ice and
snow/wetlands

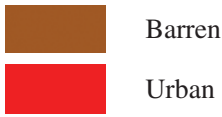

Urban

Commercial/industrial/transportation/ quarries/strip mines/gravel pits

Transitional

Figure 3. Land cover and land use on the Wind River Indian Reservation, Wyoming (modified from U.S. Geological Survey, 1992). 
applied to 46,158 acres. Specific numbers for the Reservation were not available from the census.

According to land-use data compiled by the Wyoming Water Resources Center (1998a), nearly 190,000 acres of irrigated agricultural land exist within the Reservation boundaries. Most of this land is irrigated by surface water, with the exception of a few small areas near Riverton and in the Owl Creek drainage, where irrigation wells are used. McGreevy and others (1969, p. I55) reported that irrigation on the Reservation began in the early 1860 s with simple diversions of water from the Popo Agie and Little Wind Rivers. By the 1880 s, irrigation was being developed along the Owl Creek drainage. The two largest irrigation projects on the Reservation are the Wind River Federal Irrigation Project (WRFIP) and the Riverton Reclamation Project (fig. 5). The WRFIP was established in 1905 to irrigate lands under the supervision of the Bureau of Indian Affairs along the Wind and Little Wind Rivers. The Riverton Reclamation Project was started in 1920 by the Bureau of Reclamation to irrigate land along Five Mile Creek, Muddy Creek, the Wind River, and areas adjacent to Ocean Lake. In 1914, the LeClair-Riverton Irrigation District was formed to irrigate lands along the Wind River near Riverton (fig. 5).

Poor drainage resulting in salt accumulation has been a problem in many irrigated areas on the Reservation. McGreevy and others (1969, p. I58-I66) reported numerous drainage problems associated with the WRFIP, and Peterson and others (1991, p. 10) reported that seepage and salt accumulation became apparent in the Riverton Reclamation Project area shortly after irrigation started in the 1920s. An extensive network of drains has been installed throughout the irrigated lands on the Reservation to help mitigate this problem. Most of the drains are constructed in unconsolidated surface materials and are unlined, so that some percolation of drain water to the ground water occurs. No specific study has investigated the relation between ground-water quality and irrigation drainage on the Reservation; however, studies have looked at surfacewater quality in the irrigation-drainage systems. Grasso and others (1995, p. 22-28) reported that nutrients, trace metals, and pesticides were detected in water-quality samples collected from irrigation drains in the WRFIP. Nutrients, trace metals, and pesticides were detected in water-quality samples collected from irrigation drains in the Riverton Reclamation Project as well (Peterson and others, 1991, p. 18-22).

Combined open water, perennial ice and snow, and wetlands compose about 3 percent of the land use on the Reservation (figs. 3 and 4). The three largest open-water bodies on the Reservation (Boysen Reservoir, Ocean Lake, and Bull Lake) supply irrigation water and/or receive irrigation drainage. Ocean Lake receives discharge from nine agricultural drains that are part of the Riverton Reclamation Project. Millis and Pedlar (1985) reported trace amounts of pesticides in Ocean Lake. Boysen Reservoir ultimately receives most of the drainage from the irrigated lands on the Reservation. Numerous irrigation reservoirs, stock ponds, and natural lakes exist in the lowlands. In the Wind River Range, more than 220 high- mountain lakes exist (Daddow, 1996, p. 38). Wetlands occur throughout the Reservation, but most occur in irrigated areas, in the Wind River Range, and along perennial streams.

Urban land use composes only about 0.1 percent of the total land use on the Reservation (figs. 3 and 4). The City of Riverton, with a population of 9,310 (U.S. Census Bureau, 2001), is the largest urban area, followed by Pavillion and the unincorporated communities of Arapahoe, Fort Washakie, Ethete, and Crowheart. Urban areas have many potential point sources of contaminants that could affect ground-water quality. Landfills, leaking underground storage tanks, and sewage-treatment facilities all are present on the Reservation. In addition, nonpoint sources such as pesticides and fertilizers often are applied at greater rates in urban areas than on agricultural land.

Barren areas compose about 0.6 percent of the land use on the Reservation (figs. 3 and 4). The remaining land use on the Reservation (less than 0.3 percent) is composed of commercial, industrial, and transportation infrastructure, mining, and transitional areas between land uses.

\section{Monitoring-Well Network Design}

To assist the WREQC in protecting the ground-water resources of the Reservation from being degraded by anthropogenic influences, a monitoring-well network was designed. Because the Reservation covers more than $3,500 \mathrm{mi}^{2}$ and contains many aquifers, it is important that a monitoring-well network design be focused on areas and aquifers with the greatest risk of degradation of ground-water resources. A methodology based on an arithmetic overlay model and a geographical information system (GIS) was developed to prioritize areas and aquifers by their relative risk to ground-water degradation. After areas and aquifers to be included in the network were identified, a random stratified approach was used to select specific locations for monitoring wells.

\section{Arithmetic Overlay Model}

An arithmetic overlay model was created using seven GIS data layers representing factors that have the potential to affect ground-water quality. The data layers used were the NLCD, water-well density, aquifer sensitivity, oil and natural gas fields and petroleum pipelines, sites with potential contaminant sources, sites that are known to have ground-water contamination, and National Pollutant Discharge Elimination System (NPDES) sites. The NLCD was described in the LandCover and Land-Use section of this report.

The number of known ground-water wells and their use on the Reservation are summarized in table 1, and is based on an inventory of wells done for this study. The inventory was accomplished by combining records from the USGS National Water Information System, Wyoming State Engineer's Office Water Rights Database, University of Wyoming Water 


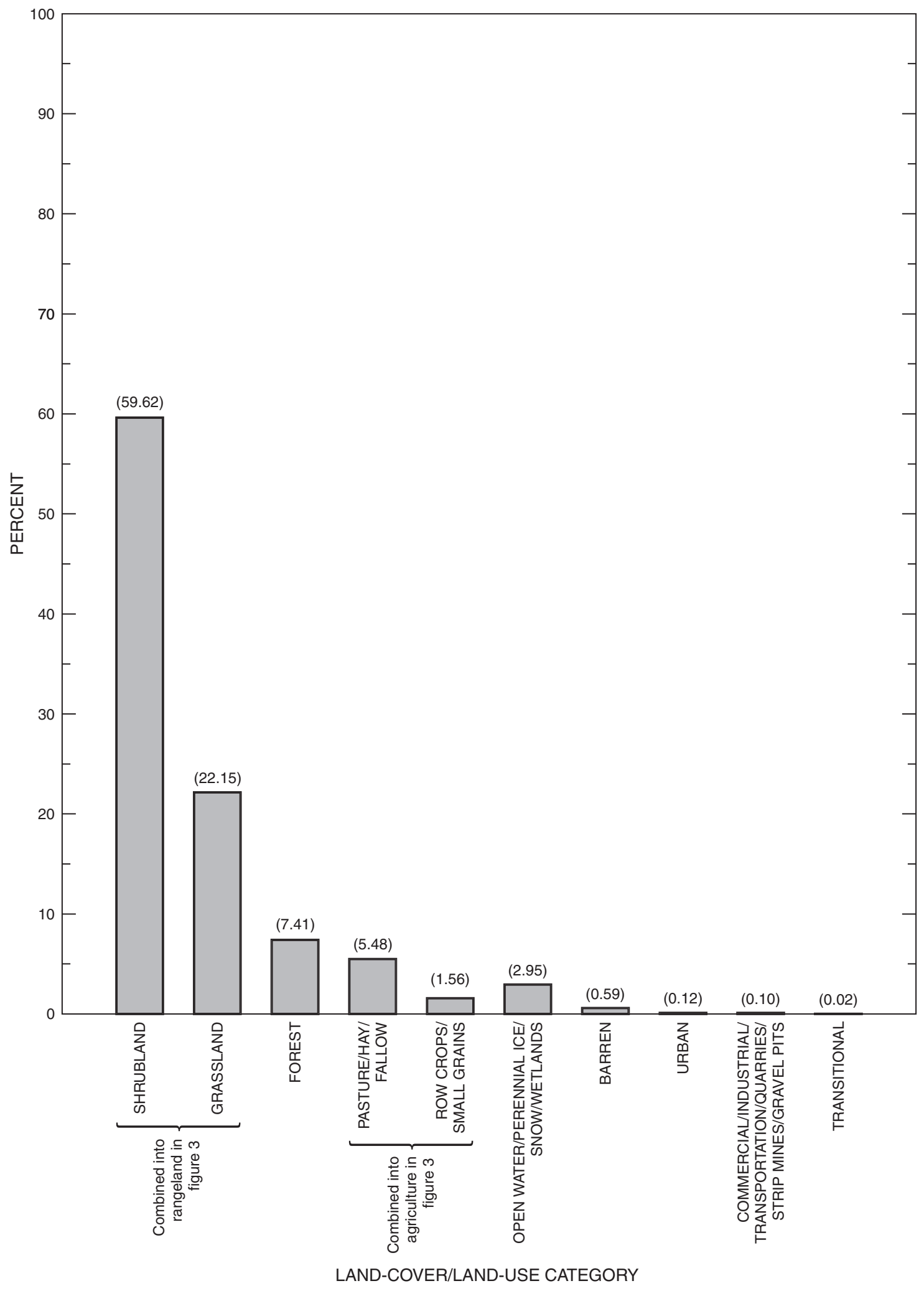

Figure 4. Land-cover and land-use categories on the Wind River Indian Reservation, Wyoming. Bars represent the area of each land-cover and land-use category expressed as a percentage of the total land area on the reservation (data from U.S. Geological Survey, 1992). 


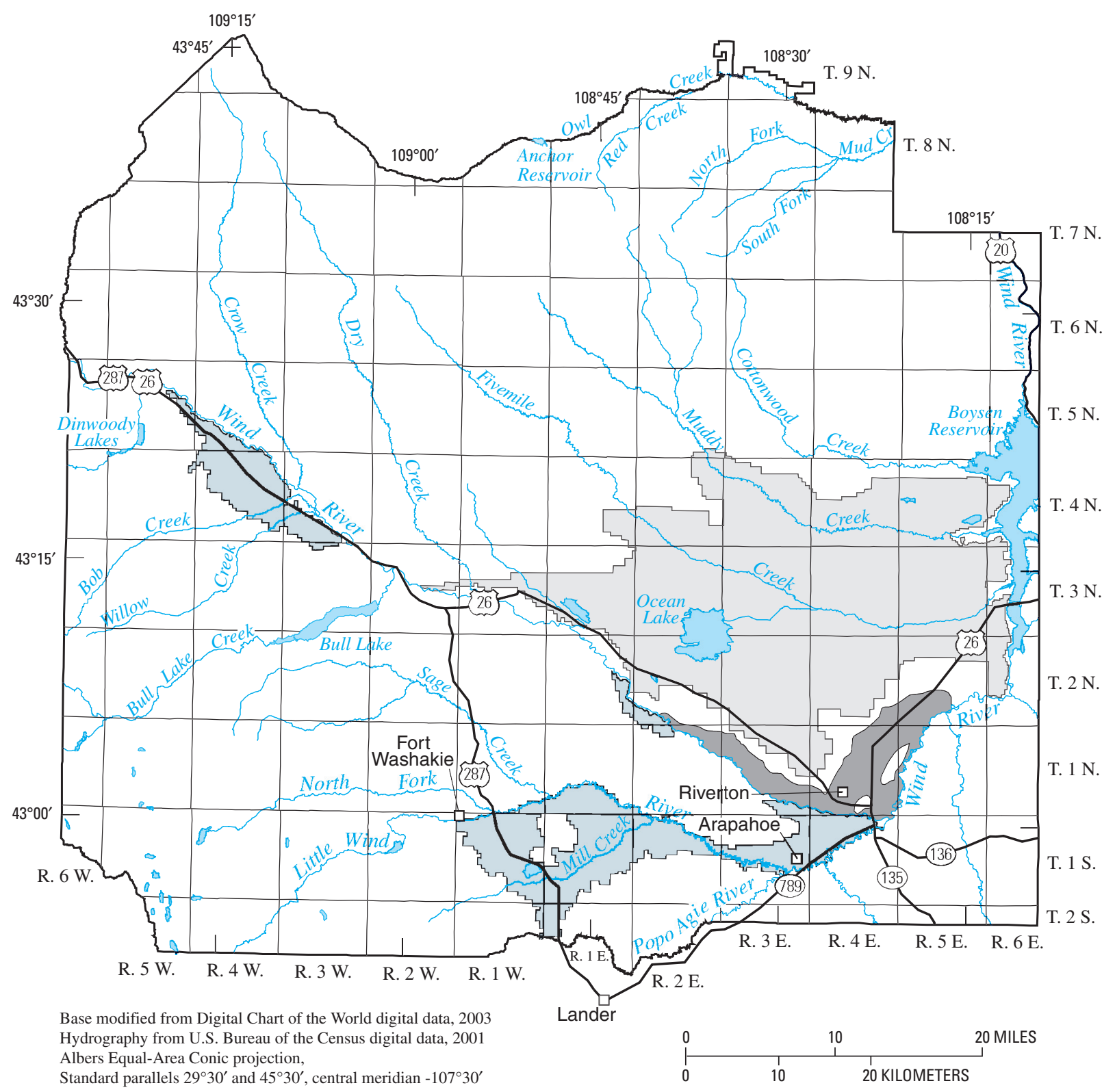

EXPLANATION

Wind River Federal Irrigation Project

Riverton Reclamation Project

LeClair-Riverton Irrigation District

Figure 5. Irrigation areas on the Wind River Indian Reservation, Wyoming. 
Resources Data System, and an older WREQC water-well database. A new water-well database for the WREQC was constructed with these records. Well information from the different sources was compared by location, depth, owner, and name. When the location, names and/or depths matched, the records from the different sources were deemed to be the same well and compiled into one database record. The new WREQC water well database includes information regarding well: location, construction, ownership, water-level data, and water-quality data. The new database was developed to assist the WREQC in managing ground-water resources on the Reservation and to identify existing wells that may be suitable for use in a ground-water-quality monitoring network.
The water-well density data layer was created using the new WREQC water-well database. All of the inventoried water wells on the Reservation (6,226 wells) were plotted in a data layer with a 500-meter $(\mathrm{m})$ buffer around them. The data layer was then edited to remove wells whose buffer was not in contact with at least three other well buffers. The purpose of this editing was to create a data layer that represented areas where ground water was utilized extensively. The final data layer consisted of the buffered areas around the remaining wells (fig. 6).

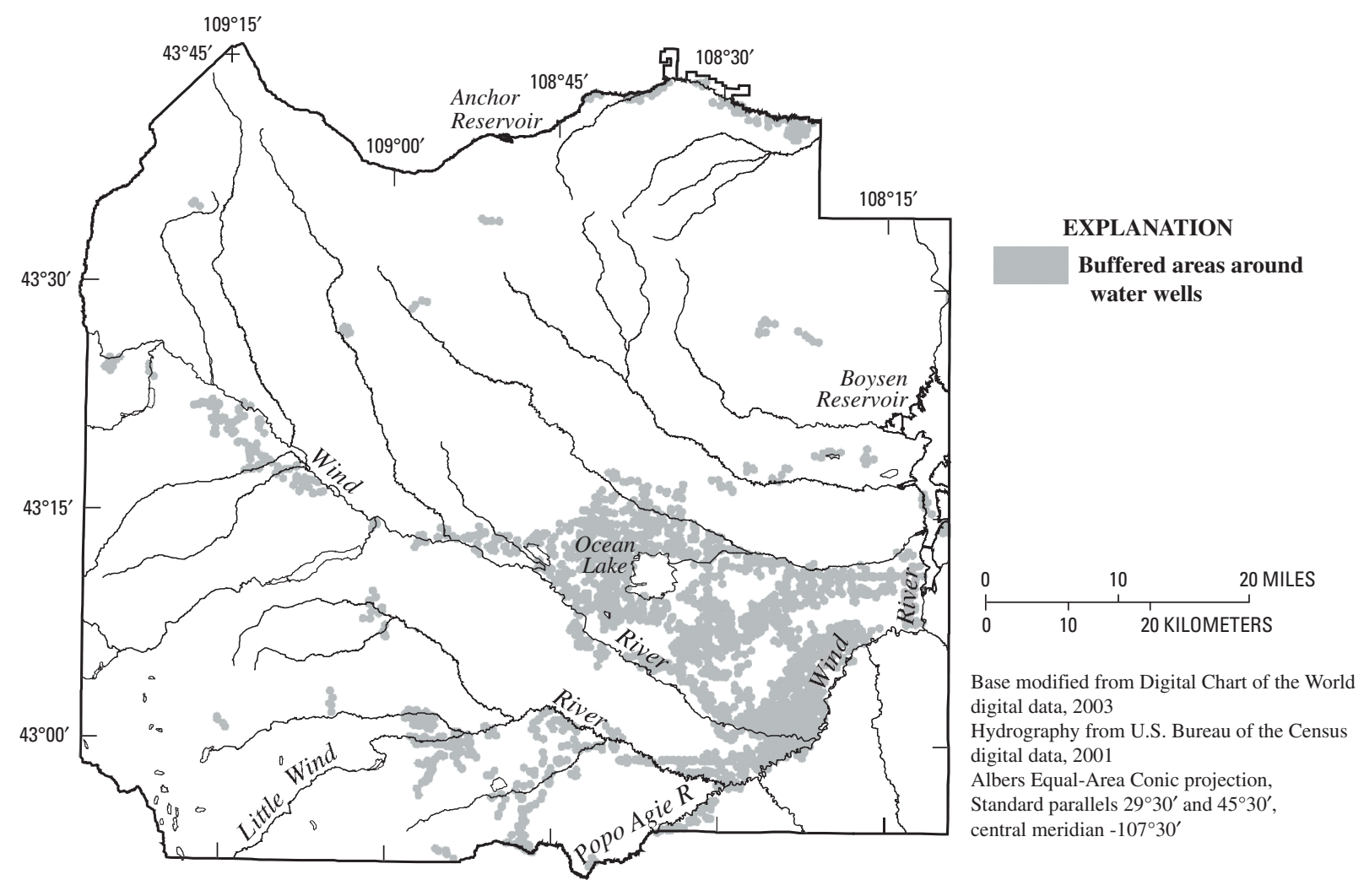

Figure 6. Water-well density layer used in arithmetic overlay model, Wind River Indian Reservation, Wyoming. 
Table 1. Inventory of ground-water wells and their use on the Wind River Indian Reservation, Wyoming.

\begin{tabular}{lcc}
\hline \multicolumn{1}{c}{ Water use } & Number of wells & $\begin{array}{c}\text { Percentage of } \\
\text { total wells }\end{array}$ \\
\hline Domestic & 3,945 & 63.4 \\
Unused & 642 & 10.3 \\
Livestock & 480 & 7.7 \\
Observation & 415 & 6.7 \\
Unknown & 350 & 5.6 \\
Miscellaneous & 250 & 4.0 \\
Public supply & 49 & 0.8 \\
Irrigation & 43 & 0.7 \\
Industrial & 38 & 0.6 \\
Commercial & 14 & 0.2 \\
\cline { 2 - 3 } Total & 6,226 & 100.0 \\
\hline
\end{tabular}

The aquifer sensitivity data layer was created by clipping the 1:100,000-scale map of aquifer sensitivity of Wyoming (Wyoming Water Resources Center, 1998b) to the Reservation boundary using the GIS. The data layer represents surficial aquifer sensitivity to surface contamination (fig. 7). The parameters used to develop the ranking were depth to initial ground water, hydrogeologic setting, soils, aquifer recharge, land surface slope, and vadose zone properties (Hamerlinck and Arneson, 1998).

The oil and natural gas fields and petroleum pipelines data layer was taken from De Bruin (2002). The data layer includes outlines of known oil and natural gas fields, including both producing and abandoned areas. The data layer also includes the location of petroleum pipelines (fig. 8). Although no buffers were used around the oil and gas fields, a 50-m buffer was placed around the pipelines. The potential hazard to ground-water quality posed by both the oil and gas fields and the petroleum pipelines was considered a single hazard. Thus, this data layer was created so that when oil or gas fields overlapped with pipelines, the pipelines were clipped out of the oil or gas field. If the pipelines had not been removed from the oil and gas fields, the arithmetic overlay model would have counted the oil and gas fields and petroleum pipelines as two separate hazards.

The data layers for the sites with potential contaminant sources and sites that are known to have ground-water contamination were created from the Wyoming Department of Environmental Quality's (1998) Wyoming Pollution Point Source database. The data layer of sites with potential contaminant sources contains the locations of non-leaking underground storage tanks, above-ground storage tanks, and municipal landfills on the Reservation (fig. 9). The data layer of sites that are known to have ground-water contamination includes the locations of leaking underground storage tanks and ground-water pollution control areas on the Reservation. A 500-m buffer also was placed around these sites to create the final data layers (fig. 9).

The NPDES data layer was provided by the WREQC for systems located on the Reservation. A 500-m buffer also was used around these sites (fig. 10).

An attempt was made to create a data layer for the arithmetic overlay model that consisted of a calibrated vulnerability to nitrate (measured as nitrite plus nitrate as nitrogen) following the methods outlined by Rupert (1999). Nonparametric statistical tests were used to look for relations between land use, soil drainage, and depth to water, with nitrate concentrations measured in ground-water samples collected on the Reservation. The source for land-use data in this task was the NLCD. Soil data were obtained from the State Soil Geographic Data Base (STATSGO) (U.S. Department of Agriculture, 1991). Depth to water data was obtained from the Wyoming Water Resources Center (1997). The USGS National Water Information System database and University of Wyoming's Water Resources Data System database were the sources for nitrate data. Because no statistically significant difference was found between nitrate concentrations in the ground-water samples and the various land-use categories, or between soil types, or different depths to water, this data layer was not used in the arithmetic overlay model.

All of the vector data layers described previously (well density, oil and natural gas fields and petroleum pipelines, sites with potential contaminant sources, sites that are known to have ground-water contamination, and NPDES sites) were converted into 100-m grid layers. The NLCD, which was already in grid format, was resampled using the nearest-neighbor method to convert its $30-\mathrm{m}$ grids to $100-\mathrm{m}$ grids. The aquifer sensitivity data layer was already in 100-m grid format. A point rating from 1 to 5 was applied to each grid in every data layer to represent the relative risk $(1=$ low risk, $5=$ high risk $)$ to potential ground-water degradation. The various categories within each data layer and their assigned rating values for corresponding grids are listed in appendix 1. Categories that have a rating of 5 do not necessarily all have the same potential risk of degrading the ground water. The value of 5 is meant to act more as a threshold than an absolute value.

The GIS arithmetic overlay model was created by stacking all of the grid data layers on top of each other and summing the individual grids in vertical columns (fig. 11). The result was a final grid data layer that contained the values of the sum of all seven layers. A prioritization map for monitoring ground water on the Reservation was created from this final grid data layer (pl. 1). The map ranks the priority for monitoring as low, medium, or high, based on the grid value. Grids that have values of 6 and less are ranked as low, values from 7 to 11 are ranked as medium, and values of 12 and greater are ranked as high (fig. 11). 


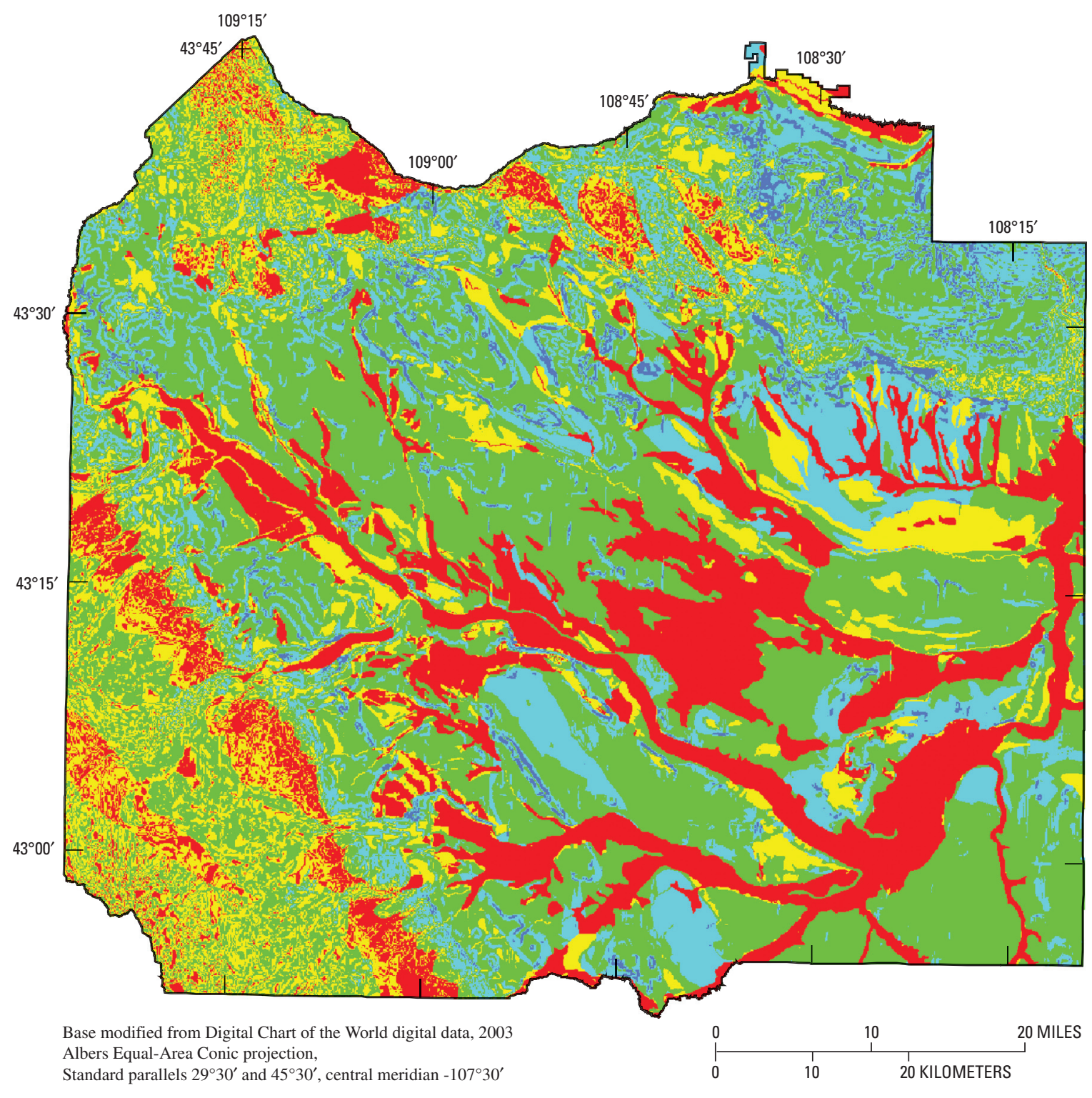

EXPLANATION

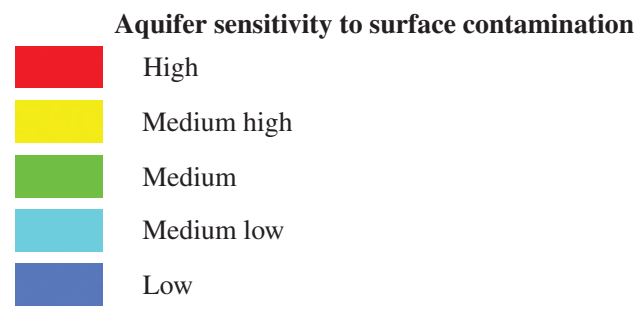

Figure 7. Aquifer sensitivity to surface contamination on the Wind River Indian Reservation, Wyoming (from Wyoming Water Resources Center, 1998b). 


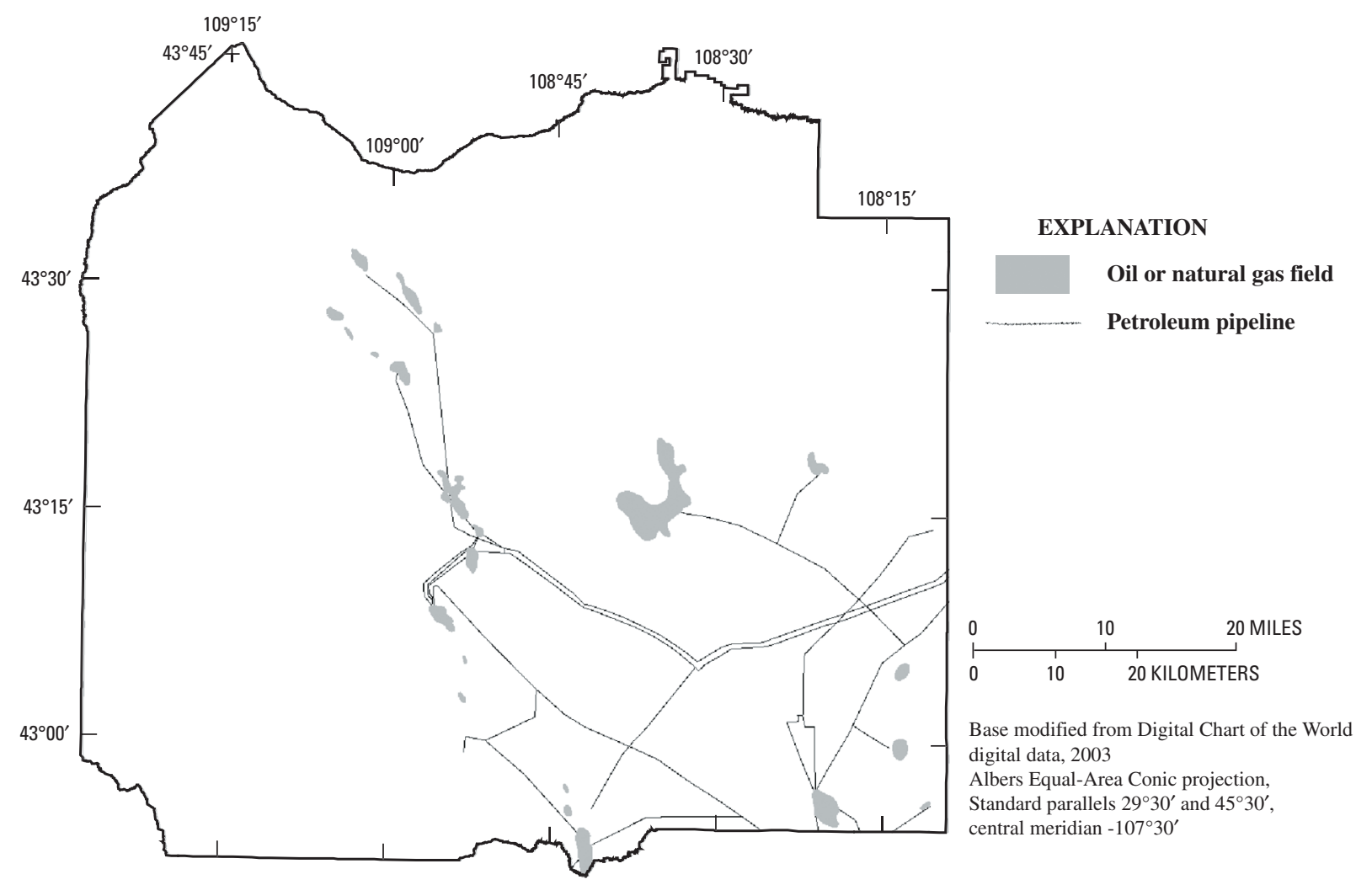

Figure 8. Oil and gas fields and petroleum pipelines on the Wind River Indian Reservation, Wyoming (from De Bruin, 2002).

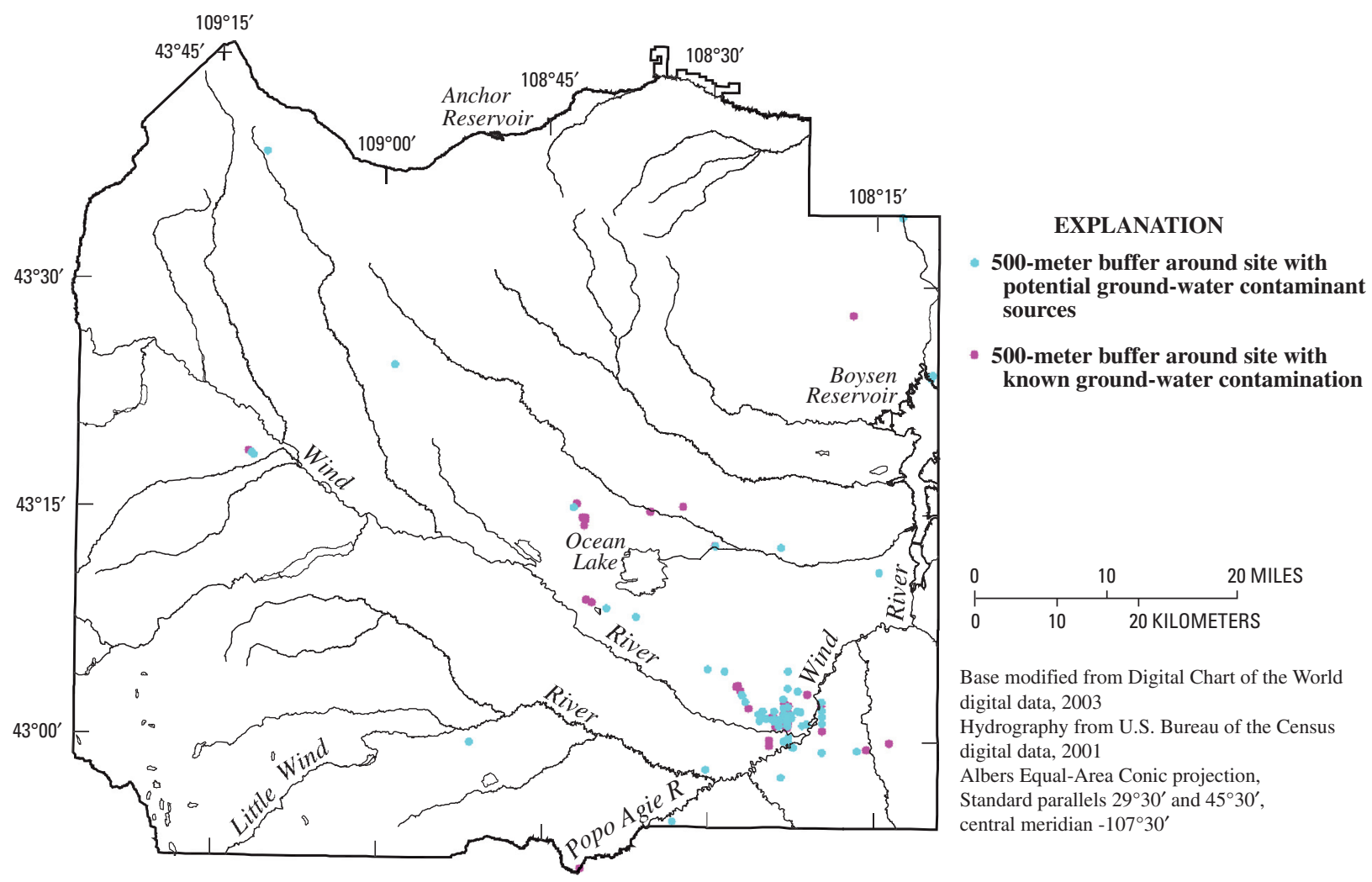

Figure 9. Sites with potential ground-water contaminant sources and sites with known ground-water contamination on the Wind River Indian Reservation, Wyoming (modified from Wyoming Department of Environmental Quality, 1998). 


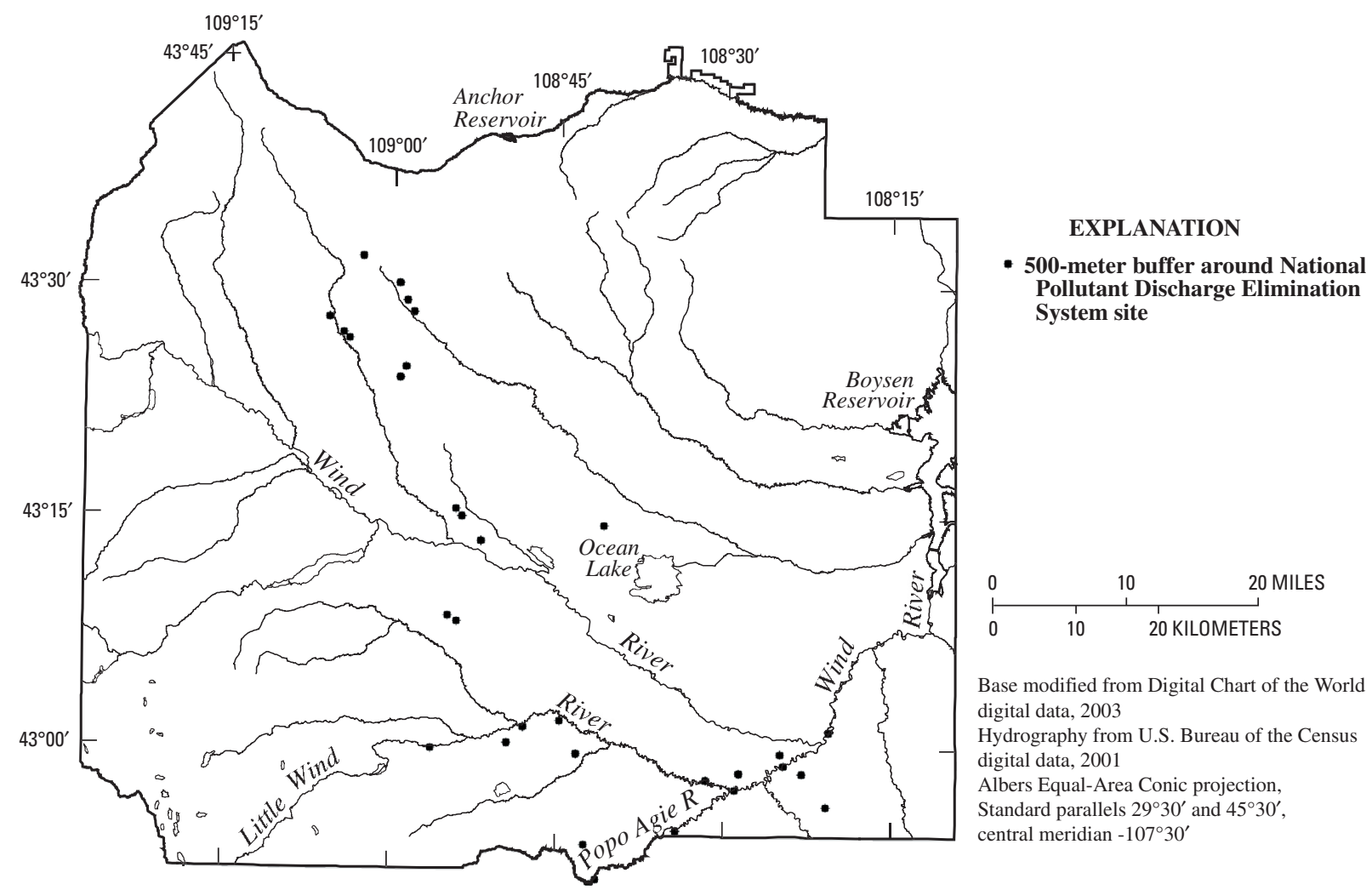

Figure 10. National Pollutant Discharge Elimination System sites on the Wind River Indian Reservation, Wyoming.

\section{Site Selection and Monitoring-Well Criteria}

In order to focus resources where they are most needed, the monitoring-well network design was restricted to areas that had a high rank on the prioritization map. Once monitoring is in place for the high-rank areas, it may be appropriate to monitor lower ranking areas as well to improve characterization of ground-water quality on the Reservation (pl. 1).

The purpose of the monitoring-well network design is to assist the WREQC in protecting the ground-water resources of the Reservation from anthropogenic activities that take place at or near the land surface. For this reason, the network was designed to sample aquifers where they occur near the surface (less than $200 \mathrm{ft}$ below the surface). As described previously, many aquifers and one aquifer system occur on the Reservation (Richter, 1981). Quaternary aquifers are the uppermost aquifer in 92 percent of the high-priority area on the prioritization map. Tertiary aquifers are the uppermost aquifer in 6 percent of the high-priority area, and all other aquifers combined are the uppermost aquifer in 2 percent of the high-priority area.

Alley (1993, p. 71) discusses how the number of samples collected from a population affects the standard error of the mean, with a large increase in the standard error as the sample size decreases below about 20. Lapham and others (1995, p. 4) recommended using a minimum of 30 wells in land-use stud- ies that are part of the USGS National Water-Quality Assessment Program (NAWQA). For these reasons the Reservation monitoring-well network was designed to include 30 wells.

\section{Site Selection}

To help minimize bias in the monitoring-well network design, an automated stratified random site-selection approach developed by Scott (1990) was used for site selection. In order to provide better areal distribution of the network than would be achieved using a simple random-selection approach, the high-priority areas from the prioritization map were divided into 30 equal areas (fig. 12). Next, a computer program (Scott, 1990) was used to select a random point within each of the equal areas. The final step was to draw a one-half mile radius circle around each point, defining the area where a monitoring well should be located (one well per site). The 30 sites selected for locating monitoring wells are shown in plate 1 . Note that all 30 circled areas delineating sites contain highpriority cells as well as medium- and/or low-priority cells. For the purposes of this report, monitoring wells need to be located within the high-priority part of the circled areas. Each circled area has an area of slightly over $3 \mathrm{mi}^{2}$ (minus any area within the site that does not have a high-priority ranking). The areas were made this large in order to make it more likely that a suitable well or suitable location for a new well 
could be found. Because of difficulties with access it may not be possible for all 30 monitoring wells to be located within a designated area. If this occurs, the monitoring well needs to be located as close as practical to its designated area, or another area may be randomly selected.

An existing well can be used if it falls within the identified monitoring area and meets the monitoring-well criteria described in the following section. If no suitable existing well can be located at a site, a new monitoring well can be installed in accordance with American Society for Testing and Materials (ASTM) standards. The well installation also needs to comply with Federal, State, Tribal, and local regulations. The use of a dedicated monitoring well constructed to ASTM standards is preferable over using non-monitoring wells such as domestic, irrigation, public supply, or stock wells. It is understood, however, that fiscal constraints often dictate that available non-monitoring wells be used.

\section{Monitoring-Well Criteria}

Because the monitoring-well network was designed to sample ground water for anthropogenic influences entering the water table through the vadose zone, it is important that the monitoring wells be designed to collect water from near the top of the aquifer. For this reason, the screened interval needs to be near the top of the water table, but below the lowest anticipated position of the water table. For the same reason, the wells need to have only one screened interval that is relatively short (less than $20 \mathrm{ft}$ ). Having a long screen interval or multiple intervals would dilute the concentrations of pollutants coming down through the vadose zone. Many other aspects of well construction affect suitability for monitoring. The following additional criteria for monitoring wells were summarized from Lapham and others (1995; 1997):

1) The hydrogeologic unit represented by the measured water level must be known.

2) The hydrogeologic unit contributing water to the well must be known.

3) Well-casing material should be polyvinyl chloride (PVC) or stainless steel.

4) Well construction must be known.

5) Well must be sufficiently developed and in connection with the aquifer.

6) Well yield must be adequate for sampling.

7) Wells that were installed to detect known contamination should be avoided.

8) If the well contains a permanently installed pump, it must be a submersible pump.

9) The sampling point should be located before any water treatment, pressure tanks, or holding tanks.
Once a well has been established for use in the monitoring network it will be important to keep up-to-date records for the well. The records should include a location map, a map of land use around the well, detailed construction information including lithology and measuring-point data, photographs of the well and surrounding land cover, and written permission from the well owner and/or land owner to sample the well. In addition to this list of basic records, other records may be required to adequately manage the monitoring-well network.

\section{Sampling Design}

After the monitoring-well network has been established, a methodology for sampling the network will be needed. Both the constituents to be monitored and the sampling frequency will need to be determined. In order to achieve the goals of documenting baseline ground-water quality conditions, detecting ground-water contamination, and documenting trends in water quality, a comprehensive sampling design for the ground-water-quality network is needed. In addition, because collecting, processing, analyzing, and interpreting water-quality samples can be expensive, it is important that the sampling design be cost-effective.

\section{Considerations for Constituents to be Monitored}

Federal and State water-quality standards are useful guides in selecting constituents for monitoring. The list of constituents for which the U.S. Environmental Protection Agency (USEPA) has established a Maximum Contaminant Level (MCL) (appendix 2) or a Secondary Maximum Contaminant Level (SMCL) (appendix 3) is extensive (U.S. Environmental Protection Agency, 2004a). In addition, the USEPA also has Health Advisory Levels for many constituents (U.S. Environmental Protection Agency, 2004b). USEPA MCLs are legally enforceable standards that apply to public water systems that provide water for human consumption through at least 15 service connections, or regularly serve at least 25 individuals (U.S. Environmental Protection Agency, 2004a). The purpose of MCLs is to protect public health by limiting the levels of contaminants in drinking water. MCLs do not apply to ground water used for livestock, irrigation, or self-supplied domestic use. They are, however, a valuable reference when assessing the suitability of water for these uses. USEPA SMCLs are non-enforceable guidelines regulating contaminants that may cause cosmetic effects (such as skin or tooth discoloration) or aesthetic effects (such as taste, odor, or color) in drinking water (U.S. Environmental Protection Agency, 2004a). Health Advisory Levels are estimates of acceptable drinking-water concentrations for a chemical substance based upon healtheffects information; health advisories are not legally enforceable standards, but serve as a guide to help Federal, State, and local officials (U.S. Environmental Protection Agency, 2004b). 


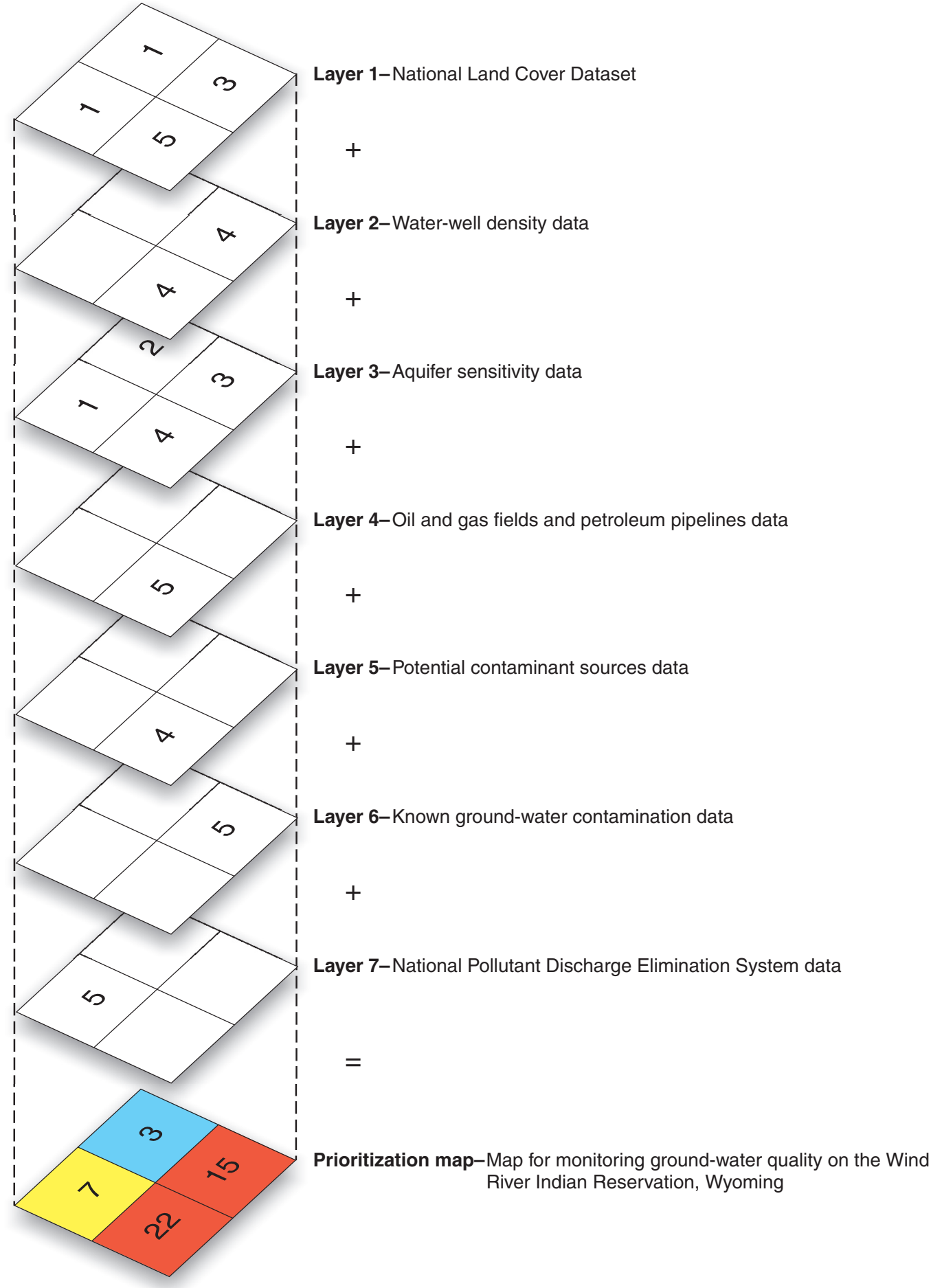

Figure 11. Diagram of arithmetic overlay model used to create prioritization map for monitoring groundwater quality on the Wind River Indian Reservation, Wyoming. The upper seven layers represent the input data layers used in the arithmetic overlay model. The bottom layer represents the prioritization map created by the model. A point rating from 1 to 5 was applied to each grid in the input data layers to represent the relative risk ( $1=$ low risk, $5=$ high risk) of degrading the ground water. Not every data layer covers 100 percent of the reservation. Grids with no values represent areas where data are absent. The values in the prioritization map grids were created by summing the values from the input grids that were vertically above the prioritization grids. The prioritization map ranks the priority for monitoring ground-water quality as either low, medium, or high, based on the grid value. Grids that have values of 6 and less are ranked as low, values from 7 to 11 are ranked as medium, and values of 12 and greater are ranked as high. 


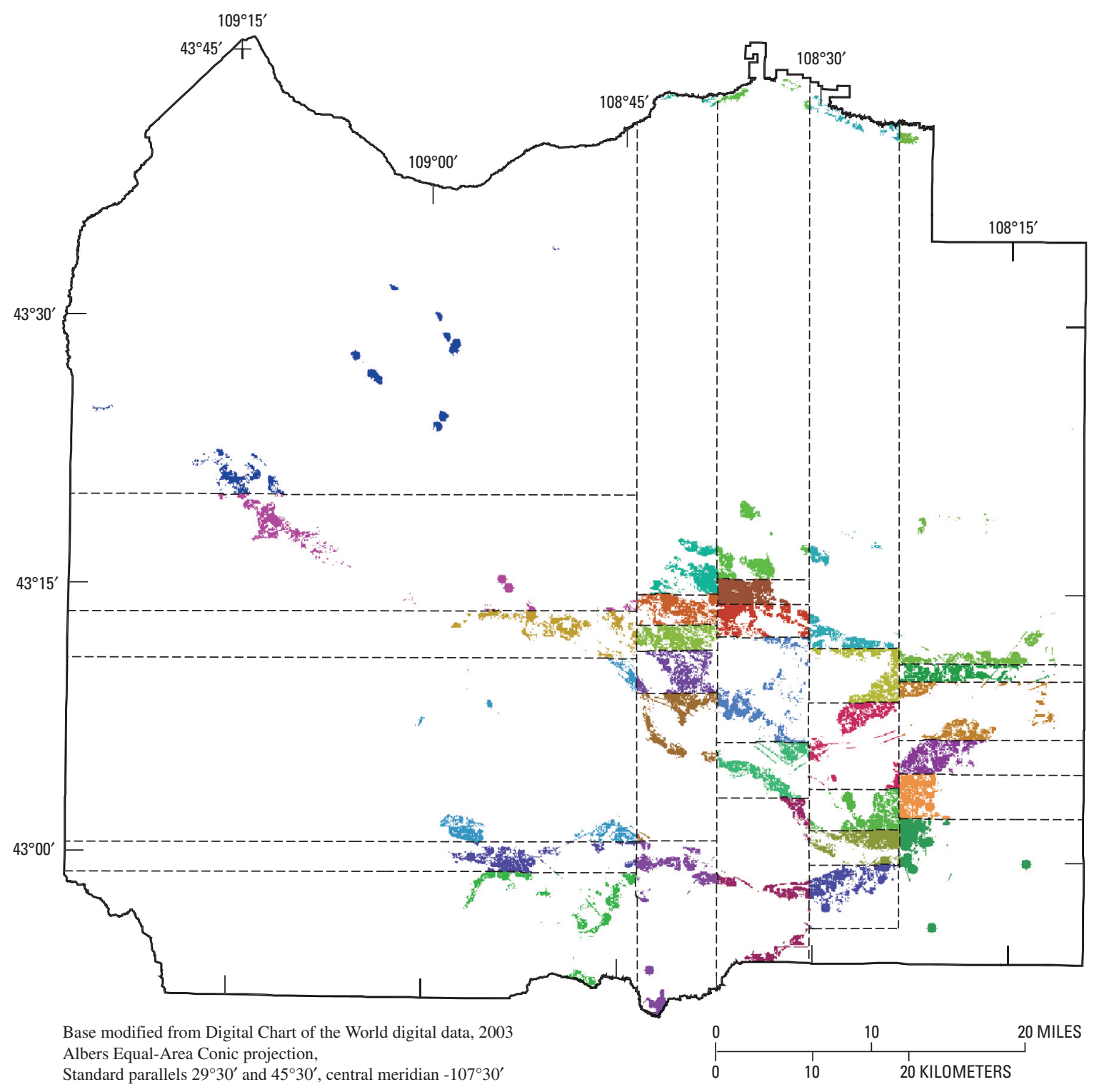

Figure 12. High-priority areas for ground-water-quality monitoring on the Wind River Indian Reservation, Wyoming, divided into 30 equal areas. Dashed lines indicate approximate boundaries between zones. Each zone contains an equal amount of high-priority land area. 
Health Advisory Levels were not considered in the sampling design for this report.

The State of Wyoming also has ground-water quality standards (Wyoming Department of Environmental Quality, 1993). The State ground-water standards are divided into seven classes; however, only four of the classes have detailed water-quality standards (appendix 4). Class I ground water is water that is suitable for domestic use. Class II ground water is water that is suitable for agricultural use where soil conditions and other factors are adequate. Class III ground water is water that is suitable for livestock. Class Special (A) is ground water that is suitable for fish and aquatic life. Classes IV through VI are for water of very poor quality, such as hydrothermal waters and oil field brines and are not discussed in this report. Wyoming ground-water-quality standards are designed to protect ground water that meets criteria of a given class from being degraded by anthropogenic activity. They are not intended to prevent ground water that does not meet the standards from being used for a particular use. Many of the constituents used to define ground-water classes in the State's water-quality standards also have a USEPA MCL, SMCL, or Health Advisory Level.

The constituents monitored in a ground-water-qualitysampling design could range from a single constituent whose presence is known or suspected, to all constituents that have a Federal and/or State water-quality standard as well as other non-regulated constituents of interest. Likewise, a groundwater-quality-sampling design could include monitoring the same constituents throughout the entire network or it could include monitoring different constituents in different parts of the network. Because of the expense associated with collecting, processing, analyzing, and interpreting water-quality samples, it is important that the ground-water-quality-sampling design target constituents of concern that have a reasonable chance of being present in the ground water. Land use, geology, hydrology, and previous studies can be used to help determine which constituents are of particular concern in a given area.

\section{Physical properties}

Physical properties of water are measured as a waterquality sample is being collected. Common physical properties include water temperature, $\mathrm{pH}$, specific conductance, dissolved-oxygen content, alkalinity, and turbidity. Once ground water flows into a well it is exposed to atmospheric gases in the well. This exposure can result in substantial chemical alteration of constituents dissolved in the ground water. For this reason, it is important to pump a well long enough prior to collecting a water-quality sample to remove all of the stagnant water in the well. This will ensure that the water-quality sample collected reflects the water quality of the aquifer, and not the water quality of the stagnant water in the well. Continuously measuring selected physical properties while pumping a well prior to collecting a water-quality sample, is a useful method to help determine when all of the stagnant water has been removed. Furthermore, physical properties such as $\mathrm{pH}$, specific conductance, dissolved-oxygen content, and alkalinity help in understanding the geochemical processes that are taking place in an aquifer. These properties also can be measured in the laboratory using sample water, but laboratory measurements may yield substantially different values because the sample water has begun to equilibrate with the atmosphere. For these reasons it may be important to include monitoring of physical properties in the sampling design.

\section{Total Dissolved Solids}

The largest (areally) known ground-water-quality concern on the Reservation is high total dissolved solids (TDS) concentrations. Although no USEPA MCL exists for TDS, this constituent can adversely affect the taste and odor of drinking water (U.S. Environmental Protection Agency, 2004a), and high TDS concentrations in irrigation water have a negative effect on crop production. High TDS also can cause scale buildup in pipes and boilers. The USEPA SMCL for TDS is $500 \mathrm{mg} / \mathrm{L}$ (appendix 3). High TDS concentrations are common in all of Wyoming's large intermontane basins. The arid climate, geology, long ground-water residence time, and low ground-water recharge rates of these basins are largely responsible for the high TDS concentrations; however, irrigation can exacerbate the problem of high TDS concentrations. Monitoring TDS in aquifers overlain by irrigated lands may be of special interest for this reason. Because most aquifers on the Reservation have moderately high to high TDS concentrations and because the analysis for TDS is relatively inexpensive, including TDS analyses for all wells in a sampling design may be important.

\section{Major ions}

Ions that are commonly present in natural waters at concentrations exceeding $1.0 \mathrm{mg} / \mathrm{L}$ are referred to as major ions. They include the cations calcium, magnesium, sodium, and potassium, and the anions sulfate, chloride, fluoride, bicarbonate, and carbonate. Fluoride is the only major ion with a USEPA MCL, but both USEPA SMCLs and State of Wyoming standards exist for several of the other major ions (appendixes 2,3 , and 4). Knowing the concentrations of major ions in ground water can help hydrologists better understand chemical processes occurring in an aquifer, and if water quality is poor, it may help them to understand the possible causes. Although major ions occur naturally in ground water, human activities such as mining and irrigation can lead to elevated levels of these constituents. Thus it may be important to include monitoring for major ions in a sampling design. 


\section{Trace Elements}

Trace elements are inorganic constituents that occur in ground water naturally at concentrations of generally less than $1 \mathrm{mg} / \mathrm{L}$. Most of the contaminants listed under inorganic chemicals in appendix 2 are considered trace elements. Trace elements in ground water have both natural and anthropogenic sources. Natural sources include the dissolution of rock and soil deposits. Anthropogenic sources include runoff from urban, industrial, and mining areas. High TDS concentrations are often an indicator of high trace-element concentrations, and as with TDS concentrations, irrigation also can exacerbate the problem of high trace-element concentrations. The presence and concentrations of trace elements depend in part on the geochemistry of the system. Various trace elements, including antimony, arsenic, barium, beryllium, cadmium, chromium, copper, lead, mercury, selenium, and thallium have various health risks (appendix 2). Other trace elements, including aluminum, boron, iron, manganese, silver, and zinc, have SMCLs and/or State of Wyoming water-quality standards (many trace elements have multiple standards, appendixes 2, 3 , and 4). In addition, some trace elements in high enough concentrations can have a negative effect on crop production. For these reasons, monitoring for trace elements in aquifers with relatively high TDS concentrations may be important. However, it also should be noted that relatively high concentrations of trace elements can occur without high TDS concentrations being present, so monitoring for trace elements should not necessarily be restricted to aquifers with high TDS concentrations. On the Reservation most aquifers do have moderately high to high TDS concentrations, so monitoring for trace elements in all wells in the network, at least initially, may be important.

\section{Nitrogen}

Nitrogen is an essential nutrient for plant growth. Both natural and anthropogenic sources can contribute nitrogen to ground water. Natural sources of nitrogen include dissolution of soil and rock, and atmospheric deposition. Anthropogenic sources also include atmospheric deposition as well as sewage and fertilizers. Most nitrogen in ground water occurs as nitrate, although it also can occur in other forms including ammonia, nitrite, and as part of organic solutes. Nitrate has a USEPA MCL of $10 \mathrm{mg} / \mathrm{L}$ as nitrogen and nitrite has a USEPA MCL of $1 \mathrm{mg} / \mathrm{L}$ as nitrogen (appendix 2). A USEPA MCL does not exist for ammonia, but the State of Wyoming has established a standard of $0.58 \mathrm{mg} / \mathrm{L}$ for class I ground water (appendix 4).

As discussed previously in the "Arithmetic Overlay Model" section of this report, an attempt was made to create a data layer for the model that consisted of a calibrated map of vulnerability to nitrate following the methods outlined by Rupert (1999). This attempt showed no statistically significant difference between nitrate concentrations in the various landuse categories, soil types, or water depths. Nearly 84 percent of the 285 nitrate samples reviewed for this study had values of $2.0 \mathrm{mg} / \mathrm{L}$ or less, whereas 4 percent of the samples reviewed had concentrations greater than the USEPA MCL of $10 \mathrm{mg} / \mathrm{L}$. Because elevated nitrogen concentrations have been documented on the Reservation and no clear correlation exists with any of the layers used to create the prioritization map, monitoring for nitrate, nitrite, and ammonia in all wells in the network, at least initially, may be important.

\section{Radionuclides}

Radionuclides are atoms that are unstable and undergo radioactive decay. Many radionuclides occur naturally, such as radon-222; radium-224, 226 and 228; and thorium-232, whereas others are created by manmade fission processes such as americium-241, cesium-137, and strontium-90. The only radionuclides with USEPA MCLs for drinking water are uranium and radium (although there is a proposal to create MCLs for radon, U.S. Environmental Protection Agency, 2004b). USEPA has established MCLs for alpha and beta particles, which are forms of radiation given off during radioactive decay (appendix 2). Even though few radionuclides have MCLs, the alpha and beta particles given off as they decay provide a measure of their effect on water quality.

Analyses for many radionuclides are expensive; however, analyses for alpha and beta particles and radon-222 generally are the least expensive. One way to reduce the cost of monitoring for radionuclides in a sampling design would be to initially limit radionuclide analyses to alpha and beta particles (and maybe radon). Additional analyses for other radionuclides could be performed if elevated alpha and beta particles were detected in water from a well. Because elevated radon concentrations in ground water have been detected in several parts of the State, it may be beneficial to also included radon monitoring in a sampling design.

\section{Pesticides}

Pesticides are a class of manmade organic chemicals that are used to control weeds, insects, and other organisms in a wide variety of agricultural and nonagricultural settings. About 40 percent of the contaminants listed in appendix 2 under the organic chemicals section are pesticides or pesticide degradates. Eddy-Miller and Norris (2000) reported low-level detections of pesticides in ground-water samples collected from shallow wells in Fremont County. Most of the samples used for the Eddy-Miller and Norris (2000) study were collected on the Reservation, including several samples with pesticide detections. The samples were collected in the summer of 1998 and spring of 1999. All of the pesticides detected were at concentrations well below the USEPA MCLs.

Because pesticides are known to be present in ground water on parts of the Reservation it may be important to include pesticide monitoring in the sampling design. However, analyses for pesticides are expensive, so focusing pesticide monitoring to areas where these compounds generally are used 
most (urban and agricultural areas) would make the sampling design more cost effective. Caution should be exercised, however, in selecting sites for pesticide monitoring because it is not always easy to tell where pesticides are being used. For example, in addition to urban and agricultural areas, pesticides often are used to control invasive species on rangeland and weeds in road ditches and railroad right-of-ways.

\section{Volatile Organic Compounds}

Volatile organic compounds (VOCs) are chemicals that produce vapors readily at room temperature and normal atmospheric pressure. VOCs typically are industrial solvents, such as trichloroethylene; fuel oxygenates, such as methyl tert-butyl ether (MTBE); or by-products produced by chlorination in water treatment, such as chloroform. VOCs often are components of petroleum fuels, hydraulic fluids, paint thinners, and dry cleaning agents. Many of the contaminants listed in appendix 2 under the organic chemicals section are VOCs (including some pesticides). Although some natural sources of VOCs exists, such as petroleum reservoirs and biogenic VOCs produced by plants, VOCs associated with anthropogenic activities, such as the extraction, transport and refining of petroleum, or production, use, and disposal of industrial chemicals, are more often the source of concern with ground water. Because analyses for VOCs are expensive and the potential sources of VOCs are usually identifiable, a costeffective sampling design may need to limit VOC monitoring to areas near potential VOC sources, such as urban areas and oil and natural gas fields and petroleum pipelines.

\section{Disinfectants and their by-products}

The disinfectants and disinfection by-products listed in appendix 2 relate to the treatment of drinking water after it is removed from its source. USEPA MCLs for these contaminants do not apply directly to in-situ ground water and are not important to include in the type of sampling design described in this report.

\section{Microorganisms}

Most of the MCLs listed for microorganisms in appendix 2 are related to the treatment of surface water in order to make it safe for human consumption, and do not apply directly to ground water. Only total coliforms, including fecal coliform and E. coli, apply directly to ground water. Coliform is a group of bacteria common in soils, plants, and animals. The coliform group is made up of several subgroups, including the fecal coliform subgroup, which is found in the intestinal tracts of warm-blooded animals, including humans. According to the USEPA (2004a), coliforms are not a health threat themselves, but they can be used to indicate whether other potentially harmful bacteria may be present. However, one form of E. coli (O157:H7) has been shown to cause illness. Monitoring for total coliforms (including fecal coliform and $E$. coli) may be important to include in a sampling design.

\section{Other constituents}

Many other chemical and biological contaminants that were not discussed in this section could affect ground-water quality and be harmful to human health and/or cause other problems. It is not practical for Federal and State agencies to establish water-quality standards for all of them. The USEPA makes determinations about which contaminants to regulate based on health risks and the likelihood that the contaminant occurs in public water systems at levels of concern. For this reason, any other potentially harmful constituents not previously discussed in this report that are suspected of being present in the ground water by the WREQC could be considered for monitoring, at least initially.

\section{Considerations for Sampling Frequency}

Many factors need to be considered in establishing a sampling frequency for a monitoring program. Depending on the natural environment, land use, and constituent of concern being monitored in an aquifer, temporal changes in groundwater quality may or may not be substantial. For example, ground-water quality in areas where a major land-use change has taken place, such as rangeland being converted to urban land use, has the potential to change in a short period of time (months or years). On the other hand, ground-water quality in areas where almost no land use change has taken place, such as in unharvested forest lands, probably will not change much even over long periods such as decades. Also, the proximity of a sampling site to a known potential source of contamination is important. For example, frequent sampling for VOCs in an area many miles from known potential sources would not be an efficient use of resources. Because collecting, processing, analyzing, and interpreting ground-water-quality samples can be expensive, it is important that these factors be considered in determining the sampling frequency for a ground-water-quality monitoring network.

Sampling frequency in a monitoring program could range from sampling for every constituent of interest at a regular time interval such as yearly, to sampling for different groups of constituents at different time intervals. A mixture of these two approaches may provide for the most efficient monitoring program. For example, the initial sampling could consist of testing for all constituents of concern in an area to establish a base line. If initial sampling results show that a given constituent of concern is not present or only present in concentrations that are much less than USEPA and State of Wyoming standards, it probably is not necessary to sample for that constituent during every sampling cycle. If elevated concentrations of constituents of concern are detected in samples from the initial sampling round, testing for those constituents during subsequent sampling cycles would be beneficial until a trend can be 
established. If the trend shows increasing concentrations of the constituent, continued monitoring for that constituent would be beneficial.

As mentioned previously, the largest (areally) known ground-water-quality concern on the Reservation is relatively high TDS concentrations. For this reason, it would be beneficial to include the collection of water-quality samples for TDS analyses in every sampling cycle. In addition, physical property measurements are important to measure each time a sample is collected because they will provide an indication if the physical properties of the ground water being sampled have changed from those previously documented. Physicalproperty measurements also improve sampling technique by indicating when all stagnant water has been removed from a well. Major-ion analyses also would be beneficial for groundwater samples collected during every sampling cycle. Some of the major ions that typically are a significant part of the TDS content of water also have USEPA MCLs and/or SMCLs (sulfate, chloride, and fluoride). Another advantage to collecting samples for major-ion analyses is that a correlation often exists between major-ion concentrations and trace-element concentrations. For this reason, performing the relatively inexpensive major-ion analyses during each sampling cycle may provide an indication of when a change is likely occurring in the trace-element concentrations in ground water from a site. Once initial testing for trace elements has been completed at a site it may not be necessary to test for them during every sampling cycle, unless a significant change in major-ion concentrations is measured. Using this approach would save resources because trace-element analyses are expensive relative to major-ion analyses.

Another factor to consider when determining the sampling frequency for a monitoring program is water-table fluctuations. Atmospheric gases are pulled into pore spaces as the pores drain when the water table of an unconfined aquifer falls. The introduction of atmospheric gases into formerly saturated pore spaces can lead to oxidation of the mineral surfaces that surround the pore spaces. Oxidized minerals will more readily dissolve into the ground water, should the water table rise again. Therefore it is possible that an increase in TDS, major ions, and trace-element concentrations could occur when water-table fluctuations occur. For this reason, sampling for these constituents may be necessary after a substantial fall and recovery of water table has occurred.

Taking all of the factors discussed so far in this section into consideration, a flexible, mixed approach to sampling frequency may be the most beneficial to use on the Reservation. For constituents that may be monitored on a regular schedule, such as physical properties, TDS, and major ions, a 5-year cycle for monitoring probably would be adequate because changes in ground-water quality generally occur gradually.

An initial sampling round that includes analyses for trace elements, nitrogen, and total coliform bacteria (including fecal coliform and E. coli) in all 30 wells also would be beneficial. Further, pesticides and pesticide degradates could be analyzed in water from wells in or near urban and agricultural areas, and
VOCs could be analyzed in water from wells in or near urban areas, oil and natural gas fields, and petroleum pipelines. If a particular constituent of concern is not detected or occurs at levels far below the USEPA MCL in water, it may only be necessary to analyze for it every 10 years instead of every 5 years. If any of these constituents of concern are present at concentrations that approach or exceed the MCL, they could be analyzed during every sampling cycle and possibly even more frequently. Changes in land use, major ion chemistry, and/or water-table altitude could indicate that the sampling design should be altered. The need for alteration could be assessed on a case-by-case basis.

Potentially harmful constituents that do not have a waterquality standard but are suspected of being present in the ground water could be monitored at least initially. After the initial sampling cycle has been completed, the need for future monitoring can be determined on a case-by-case basis.

The sampling schedule for the Reservation outlined in table 2 was based on the considerations described in this section. This sampling schedule could be altered, based on other needs and considerations not addressed in this report. It also should be noted that this sampling design is intended to provide for monitoring of nonpoint-source contaminants only.

\section{Identification of Potential Sites for Water-Level Recorders}

As mentioned previously, water-table fluctuations can affect ground-water quality. Thus, a water-table observation-well network would enhance the effectiveness of a ground-water-quality monitoring network. In particular, an observation-well network equipped with water-level recorders that have the capability to collect a continuous water-table record would be beneficial, especially in areas where substantial changes in the water table are likely to occur over short periods of time. Examples of these areas include irrigated agricultural lands, municipal well fields, and rural housing developments where domestic wells are close to each other. Water-table changes in these areas may occur too rapidly to accurately track water-table fluctuations using periodic measurements.

Ground-water withdrawals for municipal, industrial, stock, and self-supplied domestic uses on the Reservation, in conjunction with surface-water irrigation, probably cause the water table to be in continuous flux over large areas. An extensive network of shallow wells equipped with water-level recorders would be required to fully understand how these activities affect the water table. However, for the purposes of supporting a ground-water-quality monitoring network, a simple network of water-level observation wells would be useful and cost effective. Patterns of how humans use water may vary greatly between different types of water use, but in an area the size of the Reservation, the patterns of a specific water-use category may not vary much from location to loca- 
tion. For example, similar amounts of irrigation water probably are applied to most irrigated lands on the Reservation. Likewise, in most rural areas with a high density of domestic wells, ground water likely is used more during the summer months than during the winter. The same probably is true for municipal wells that supply urban areas. On the other hand, ground-water withdrawals for industrial uses may be fairly constant throughout the year.

Water-level recorders installed in shallow wells located in at least one of each of the following areas would provide important information for the ground-water-quality monitoring network: (1) agricultural area where surface-water irrigation is used, (2) rural housing development with a high density of wells, (3) area where ground water is used extensively for municipal and/or industrial purposes, and (4) areas where ground water is not utilized and not affected by surface water. Water-level data from the well located in an area where ground water is not utilized and not affected by surface water would provide an indication of how the water table responds to changes in climate. These data could then assist in determining the effect of human activity on water-table levels in areas where pumping and irrigation occur.

Table 2. Sampling schedule designed for a 30-well ground-water-quality monitoring network on the Wind River Indian Reservation, Wyoming.

\begin{tabular}{|c|c|c|}
\hline Constituents & Sampling frequency & Remarks \\
\hline Major ions & 5 years ${ }^{1}$ & \\
\hline Trace elements & 10 years $^{1}$ & $\begin{array}{l}\text { Use 5-year sampling frequency if concentrations are found to be } \\
\text { elevated }\end{array}$ \\
\hline Nitrogen & 10 years $^{1}$ & $\begin{array}{l}\text { Use 5-year sampling frequency if concentrations are found to be } \\
\text { elevated }\end{array}$ \\
\hline Radionuclides & 10 years $^{1}$ & $\begin{array}{l}\text { Use 5-year sampling frequency if concentrations are found to be } \\
\text { elevated }\end{array}$ \\
\hline Volatile organic compounds (VOCs) & 10 years $^{1}$ & $\begin{array}{l}\text { Monitor only in or near areas where potential sources of VOCs are } \\
\text { known or suspected. Use 5-year sampling frequency if concentra- } \\
\text { tions are found to be elevated }\end{array}$ \\
\hline $\begin{array}{l}\text { Total coliform bacteria } \\
\text { (including fecal coliform and } E \text {. coli) }\end{array}$ & 10 years $^{1}$ & $\begin{array}{l}\text { Use 5-year sampling frequency if concentrations are found to be } \\
\text { elevated }\end{array}$ \\
\hline Others & variable & $\begin{array}{l}\text { Potentially harmful constituents that do not have a water-quality stan- } \\
\text { dard but are suspected of being present in the ground water }\end{array}$ \\
\hline
\end{tabular}

\footnotetext{
${ }^{1}$ Sampling frequency may need to be increased if one or more of the following occur: high concentrations of constituents are found, land-use changes take place, substantial water-table fluctuations occur, or any other situation occurs that could potentially adversely affect ground-water quality.
} 


\section{Summary}

The Wind River Indian Reservation, Wyoming, is located in parts of Fremont and Hot Springs Counties and has a total land area of more than 3,500 $\mathrm{mi}^{2}$. Ground water on the Wind River Indian Reservation is a valuable resource for the Shoshone and Northern Arapahoe tribal members and others who live on the Reservation. In addition to being the major source of water for the rural population on the Reservation, ground water also is used for municipal, industrial, commercial, mining, livestock, and irrigation uses. Protection of ground-water resources is necessary for the continued economic success and quality of life on the Reservation.

The U.S. Geological Survey, in cooperation with the Wind River Environmental Quality Commission, conducted a study to identify areas of the Reservation that have the highest potential for ground-water contamination and developed a comprehensive plan to monitor these areas. First, an arithmetic overlay model for the Wind River Indian Reservation was created using seven geographic information system data layers representing factors that have the potential to affect ground-water quality. The data layers used were: the National Land Cover Dataset, water well density, aquifer sensitivity, oil and natural gas fields and petroleum pipelines, sites with potential contaminant sources, sites that are known to have ground-water contamination, and National Pollutant Discharge Elimination System sites. Second, a prioritization map for monitoring ground-water quality on the Reservation was created using the model. The prioritization map ranks the priority for monitoring ground-water quality in different areas of the Reservation as low, medium, or high.

Third, to help minimize bias in the monitoring-well network design, an automated stratified random site-selection approach was used for site selection. In order to provide better areal distribution of the network than would be achieved using a simple random-selection approach, the high-priority areas from the prioritization map were divided into 30 equal-area cells. Next, a computer program was used to select a random point within each equal-area cell. The final step was to draw a one-half mile radius circle around each point. This defined 30 potential areas for locating monitoring wells.

Fourth, the constituents to be monitored and the sampling frequency were assessed based on Federal and State water-quality standards and on water-quality results from previous studies. The sampling schedule designed for this study included monitoring for physical properties, total dissolved solids, and major ions, on a regular schedule with a 5-year interval. The design also included initial sampling for trace elements, nitrogen, radionuclides, and total coliform bacteria (including fecal coliform and E. coli) in all 30 wells. Further, the design included pesticide analyses for water from wells in or near urban and agricultural areas and analyses for volatile organic compounds (VOCs) in water from wells in or near urban areas or oil and natural gas fields and petroleum pipelines. Sampling for trace elements, nitrogen, total coliform bacteria, pesticides, and VOCs may only be necessary every 10 years if these constituents are not detected in the ground water, or occur at very low concentrations.

Fifth, criteria for potential sites to install water-level recorders were assessed. Water-level recorders installed in shallow wells located in at least one of each of the following areas would provide important information for the groundwater-quality monitoring network: (1) agricultural area where surface-water irrigation is used, (2) rural housing development with a high density of wells, (3) area where ground water is used extensively for municipal and/or industrial purposes, and (4) area where ground water is not utilized and not affected by surface water.

\section{References}

Alley, W.M., 1993, Ground-water quality surveys, in Alley, W.M. ed., Regional ground-water quality: New York, Van Nostrand Reinhold, p. 63-85.

Anderson, J.F., Hardy, E.E., Roach, J.T., and Witmer, R.E., 1976, A land use and land cover classification system for use with remote sensor data: U.S. Geological Survey Professional Paper 964, 28 p.

Battaglin, W.A., and Goolsby, D.A., 1995, Spatial data in geographic information system format on agricultural chemical use, land use, and cropping practices in the United States: U.S. Geological Survey Water-Resources Investigations Report 94-4176, 87 p. Online version accessed November 16, 2001, at URL http://water.usgs.gov/public/pubs/bat/ bat000.html

Blackstone, D.L., Jr., 1993, Precambrian basement map of Wyoming, in Snoke, A.W., Steidtmann, J.R., and Roberts, S.M., eds., Geology of Wyoming: Laramie, Geological Survey of Wyoming Memoir No. 5, Map Series 43, scale $1: 1,000,000$.

Daddow, R.L., 1996, Water resources of the Wind River Indian Reservation, Wyoming: U.S. Geological Survey WaterResources Investigation Report 95-4223, 121 p.

De Bruin, R.H., 2002, Oil and gas fields of Wyoming: Laramie, Wyoming State Geological Survey Map Series 55, 1 sheet, scale 1:500,000, also available as digital data.

Eddy-Miller, C.A., and Norris, J.R., 2000, Pesticides in ground water - Fremont County, Wyoming, 1998-99: U.S. Geological Survey Fact Sheet 035-00, 4 p.

Grasso, D.N., Jennings, M.E., and Sadler, W.J., 1995, Field screening of water quality, bottom sediment, and biota associated with irrigation drainage, Wind River Indian Reservation, Wyoming, 1992-93: U.S. Geological Survey Open-File Report 95-121, 41 p. 
Hamerlinck, J.D., and Arneson, C.S., eds., 1998, Wyoming ground water vulnerability assessment handbook, Volume 1. Background, model development, and aquifer sensitivity analysis: Laramie, University of Wyoming, Spatial Data and Visualization Center Publication SDVC 98-01-1.

Johnson, R.C., Finn, T.M., Keefer, W.R., and Szmajter, R.J., 1996, Geology of upper Cretaceous and Paleocene gas-bearing rocks, Wind River Basin, Wyoming: U.S. Geological Survey Open-File Report 96-090, 120 p.

Keefer, W.R., 1965, Stratigraphy and geologic history of the uppermost Cretaceous, Paleocene, and lower Eocene rocks in the Wind River Basin, Wyoming: U.S. Geological Survey Professional Paper 495-A, 77 p.

Keefer, W.R., 1970, Structural geology of the Wind River Basin, Wyoming: U.S. Geological Survey Professional Paper 495-D, 35 p.

Keefer, W.R., and Van Lieu, J.A., 1966, Paleozoic formations in the Wind River Basin, Wyoming: U.S. Geological Survey Professional Paper 495-B, 60 p.

Lapham, W.W., Wilde, F.D., and Koterba, M.T., 1995, Ground-water data-collection protocols and procedures for the National Water-Quality Assessment Program—selection, installation, and documentation of wells, and collection of related data: U.S. Geological Survey Open-File Report 95-398, $69 \mathrm{p}$.

Lapham, W.W., Wilde, F.D., and Koterba, M.T., 1997, Guidelines and standard procedures for studies of ground-water quality - selection and installation of wells, and supporting documentation: U.S. Geological Survey Water-Resources Investigations Report 96-4233, $110 \mathrm{p}$.

McGreevy, L.J., Hodson, W.G., and Rucker, S.J., IV, 1969, Ground-water resources of the Wind River Indian Reservation, Wyoming: U.S. Geological Survey Water-Supply Paper 1576-I, 145 p.

Millis, R.L., and Pedlar, D.E., 1985, Ocean lake eutrophication and water quality study: Cheyenne, Wyoming Game and Fish Department, Fish Division Completion Report, 61 p.

Peterson, D.A., Harms, T.F., Ramirez, P., Jr., Allen, G.T., and Christenson, A.H., 1991, Reconnaissance investigation of water quality, bottom sediment, and biota associated with irrigation drainage in the Riverton Reclamation Project, Wyoming, 1988-89: U.S. Geological Survey WaterResources Investigations Report 90-4187, 84 p.

Raisz, Erwin, 1972, Physiographic provinces in the Rocky Mountain region and landforms of western United States, in Geologic atlas of the Rocky Mountain region: Denver, Colorado, Rocky Mountain Association of Geologists, p. 30.
Richter, H.R., Jr., 1981, Occurrence and characteristics of ground water in the Wind River Basin, Wyoming: Laramie, University of Wyoming Water Resources Research Institute, report to U.S. Environmental Protection Agency, Volume IV-A, 149 p.

Rupert, M.G., 1999, Improvements to the DRASTIC groundwater vulnerability mapping method: U.S. Geological Survey Fact Sheet FS-066-99, 6 p.

Scott, J.C., 1990, Computerized stratified random site-selection approaches for design of a ground-water-quality sampling network: U.S. Geological Survey Water-Resources Investigations Report 90-4101, 109 p.

U.S. Census Bureau, 2001, American factfinder geographic comparison table: digital data accessed November 27, 2001 at URL http://factfinder.census.gov/servlet/BasicFactsTable? lang $=e n \& \_v t \_n a m e=D E C \_2000 \_P L_{-} U \_G C T P L_{-}$ ST7\&_geo_id $=04000 U S 56$

U.S. Census Bureau, 2004, American factfinder select population groups comparison table: digital data accessed January 20, 2004 at URL http://factfinder.census.gov/ servlet/DTTable?_bm=y\&-context $=d t \&-r e g=D E C \_2000_{-}$ $S F 2 \_U \_P C T 001: 001 \&-d s \_n a m e=D E C \_2000 \_S F 1 \_U \&-$ $C O N T E X T=d t \&-m t \_n a m e=D E C \_2000 \_S F 1 \_U \_P 001 \&-t r e e$ $i d=4001 \&-r e d o L o g=f a l s e \&-a l l \_g e o \_t y p e s=N \&-g e o \_i d=$ 25200US4610R\&-search_results $=01000 U S \&$-_lang $=e n$

U.S. Department of Agriculture, 1991, State soil geographic data base (STATSGO): U.S. Department of Agriculture, Soil Conservation Service, Miscellaneous Publication no. $1492,88 \mathrm{p}$.

U.S. Department of Commerce, Economic Development Administration, 2004, Wind River Reservation: accessed November 4, 2004 at URL http://www.eda.gov/ImageCache/EDAPublic/documents/pdfdocs/44wyoming_2epdf/ vl/44wyoming.pdf

U.S. Environmental Protection Agency, 2004a, List of drinking water contaminants and MCLs: accessed August 2, 2004 at URL http://www.epa.gov/safewater/mcl.html\#3

U.S. Environmental Protection Agency, 2004b, 2004 addition of the drinking water standards and health advisories: U.S. Environmental Protection Agency 822-R-04-005, 12 p.

U.S. Geological Survey, 1992, National Land Cover Dataset (NLCD): Sioux Falls, South Dakota, U.S. Geological Survey digital data.

U.S. Geological Survey, 2001, 1995 Water-use data: digital data accessed July 9, 2001, at URL http://water.usgs.gov/ watuse/spread95.html

Wyoming Department of Agriculture, 2001, Wyoming agricultural statistics 2001: Cheyenne, Wyoming Department of Agriculture, $98 \mathrm{p}$. 
Wyoming Department of Environmental Quality, 1993,

Quality standards for Wyoming groundwaters: Cheyenne, Wyoming Department of Environmental Quality, Chapter VIII, $87 \mathrm{p}$.

Wyoming Department of Environmental Quality, 1998, Wyoming pollution point source database: Cheyenne, Wyoming.

Wyoming Water Resources Center, 1997, Depth to initial ground water in feet, for the state of Wyoming (excluding Yellowstone National Park) at 1:100,000-scale: Laramie, University of Wyoming Spacial Data and Visualization Center, digital data, scale 1:100,000.

Wyoming Water Resources Center, 1998a, Agricultural land use of Wyoming: Laramie, University of Wyoming Spatial Data and Visualization Center, digital data, scale 1:58,200.

Wyoming Water Resources Center, 1998b, Aquifer sensitivity of Wyoming at 1:100,000-scale: Laramie, University of Wyoming Spatial Data and Visualization Center, digital data, scale 1:100,000.

Zelt, R.B., Boughton, G.K., Miller, K.A., Mason, J.P., and Gianakos, L.M., 1999, Environmental setting of the Yellowstone River Basin, Montana, North Dakota, and Wyoming: U.S. Geological Survey Water-Resources Investigations Report 98-4269, 112 p. 
Appendixes 1-4 
Appendix 1. Point rating scheme for arithmetic overlay model used to create the ground-water-quality-monitoring prioritization map on the Wind River Indian Reservation, Wyoming.

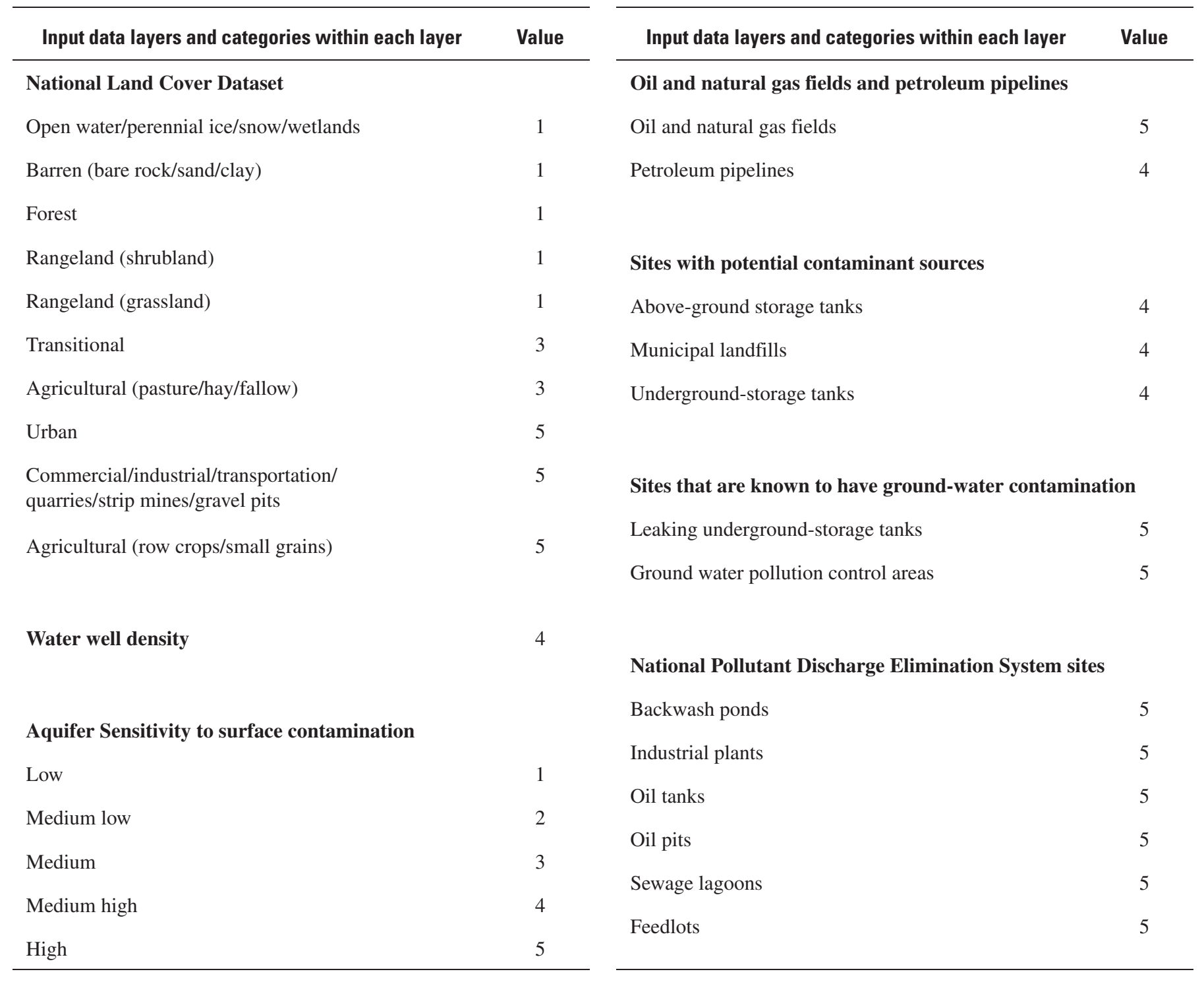


Appendix 2. U.S. Environmental Protection Agency Maximum Contaminant Levels (MCLs) for drinking water (from U.S. Environmental Protection Agency, 2004a).

\begin{tabular}{|c|c|c|c|}
\hline Contaminant & $\operatorname{MCL}^{1}(\mathrm{mg} / \mathrm{L})^{2}$ or $\mathrm{TT}^{1}$ & $\begin{array}{l}\text { Potential health effects from } \\
\text { ingestion of water }\end{array}$ & $\begin{array}{l}\text { Sources of contaminant in } \\
\text { drinking water }\end{array}$ \\
\hline \multicolumn{4}{|c|}{ Inorganic chemicals } \\
\hline Antimony & 0.006 & $\begin{array}{l}\text { Increase in blood cholesterol; } \\
\text { decrease in blood sugar }\end{array}$ & $\begin{array}{l}\text { Discharge from petroleum } \\
\text { refineries; fire retardants; } \\
\text { ceramics; electronics; solder }\end{array}$ \\
\hline Arsenic & 0.010 & $\begin{array}{l}\text { Skin damage or problems with } \\
\text { circulatory systems, and may } \\
\text { have increased risk of cancer }\end{array}$ & $\begin{array}{l}\text { Erosion of natural deposits; } \\
\text { runoff from orchards, runoff } \\
\text { from glass- and electronics- } \\
\text { production wastes }\end{array}$ \\
\hline $\begin{array}{l}\text { Asbestos } \\
\quad \text { (fiber >10 micrometers) }\end{array}$ & $7 \mathrm{MFL}^{1}$ & $\begin{array}{l}\text { Increased risk of developing } \\
\text { benign intestinal polyps }\end{array}$ & $\begin{array}{l}\text { Decay of asbestos cement in } \\
\text { water mains; erosion of natu- } \\
\text { ral deposits }\end{array}$ \\
\hline Barium & 2 & Increase in blood pressure & $\begin{array}{l}\text { Discharge of drilling wastes; } \\
\text { discharge from metal re- } \\
\text { fineries; erosion of natural } \\
\text { deposits }\end{array}$ \\
\hline Beryllium & 0.004 & Intestinal lesions & $\begin{array}{l}\text { Discharge from metal refineries } \\
\text { and coal-burning factories; } \\
\text { discharge from electrical, } \\
\text { aerospace, and defense } \\
\text { industries }\end{array}$ \\
\hline Cadmium & 0.005 & Kidney damage & $\begin{array}{l}\text { Corrosion of galvanized pipes; } \\
\text { erosion of natural deposits; } \\
\text { discharge from metal refiner- } \\
\text { ies; runoff from waste batter- } \\
\text { ies and paints }\end{array}$ \\
\hline Copper & $\mathrm{TT}^{6} ;$ Action Level=1.3 & $\begin{array}{l}\text { Short-term exposure: Gastroin- } \\
\text { testinal distress } \\
\text { Long-term exposure: Liver or } \\
\text { kidney damage } \\
\text { People with Wilson's Disease } \\
\text { should consult their personal } \\
\text { doctor if the amount of cop- } \\
\text { per in their water exceeds the } \\
\text { Action Level }\end{array}$ & $\begin{array}{l}\text { Corrosion of household plumb- } \\
\text { ing stems; erosion of natural } \\
\text { deposits }\end{array}$ \\
\hline $\begin{array}{l}\text { Cyanide } \\
\text { (as free cyanide) }\end{array}$ & 0.2 & $\begin{array}{l}\text { Nerve damage or thyroid } \\
\text { problems }\end{array}$ & $\begin{array}{l}\text { Discharge from steel/metal fac- } \\
\text { tories; discharge from plastic } \\
\text { and fertilizer factories }\end{array}$ \\
\hline
\end{tabular}


Appendix 2. U.S. Environmental Protection Agency Maximum Contaminant Levels (MCLs) for drinking water (from U.S. Environmental Protection Agency, 2004a).-Continued

\begin{tabular}{|c|c|c|c|}
\hline Contaminant & $\mathrm{MCL}^{1}(\mathrm{mg} / \mathrm{L})^{2}$ or TT${ }^{1}$ & $\begin{array}{l}\text { Potential health effects from } \\
\text { ingestion of water }\end{array}$ & $\begin{array}{l}\text { Sources of contaminant in } \\
\text { drinking water }\end{array}$ \\
\hline \multicolumn{4}{|c|}{ Inorganic chemicals-Continued } \\
\hline Fluoride & 4.0 & $\begin{array}{l}\text { Bone disease (pain and tender- } \\
\text { ness of the bones). Children } \\
\text { may get mottled teeth }\end{array}$ & $\begin{array}{l}\text { Water additive that promotes } \\
\text { strong teeth; erosion of } \\
\text { natural deposits; discharge } \\
\text { from fertilizer and aluminum } \\
\text { factories }\end{array}$ \\
\hline Lead & $\mathrm{TT}^{6} ;$ Action Level $=0.015$ & $\begin{array}{l}\text { Infants and children: delays in } \\
\text { physical or mental develop- } \\
\text { ment; children could show } \\
\text { slight deficits in attention } \\
\text { span and learning abilities } \\
\text { Adults: kidney problems; high } \\
\text { blood pressure }\end{array}$ & $\begin{array}{l}\text { Corrosion of household plumb- } \\
\text { ing systems; erosion of } \\
\text { natural deposits }\end{array}$ \\
\hline Nitrate (measured as nitrogen) & 10 & $\begin{array}{l}\text { Infants younger than } 6 \text { months } \\
\text { who drink water containing } \\
\text { nitrate in excess of the MCL } \\
\text { could become seriously ill } \\
\text { and, if untreated, may die. } \\
\text { Symptoms include short- } \\
\text { ness of breath and blue-baby } \\
\text { syndrome. }\end{array}$ & $\begin{array}{l}\text { Runoff from fertilizer use; } \\
\text { leaching from septic tanks, } \\
\text { sewage; erosion of natural } \\
\text { deposits }\end{array}$ \\
\hline Selenium & 0.05 & $\begin{array}{l}\text { Hair or fingernail loss; numb- } \\
\text { ness in fingers or toes; circu- } \\
\text { latory problems }\end{array}$ & $\begin{array}{l}\text { Discharge from petroleum } \\
\text { refineries; erosion of natural } \\
\text { deposits; discharge from } \\
\text { mines }\end{array}$ \\
\hline Thallium & 0.002 & $\begin{array}{l}\text { Hair loss; changes in blood; } \\
\text { kidney, intestine, or liver } \\
\text { problems }\end{array}$ & $\begin{array}{l}\text { Leaching from ore-process- } \\
\text { ing sites; discharge from } \\
\text { electronics, glass, and drug } \\
\text { factories }\end{array}$ \\
\hline
\end{tabular}


Appendix 2. U.S. Environmental Protection Agency Maximum Contaminant Levels (MCLs) for drinking water (from U.S. Environmental Protection Agency, 2004a).-Continued

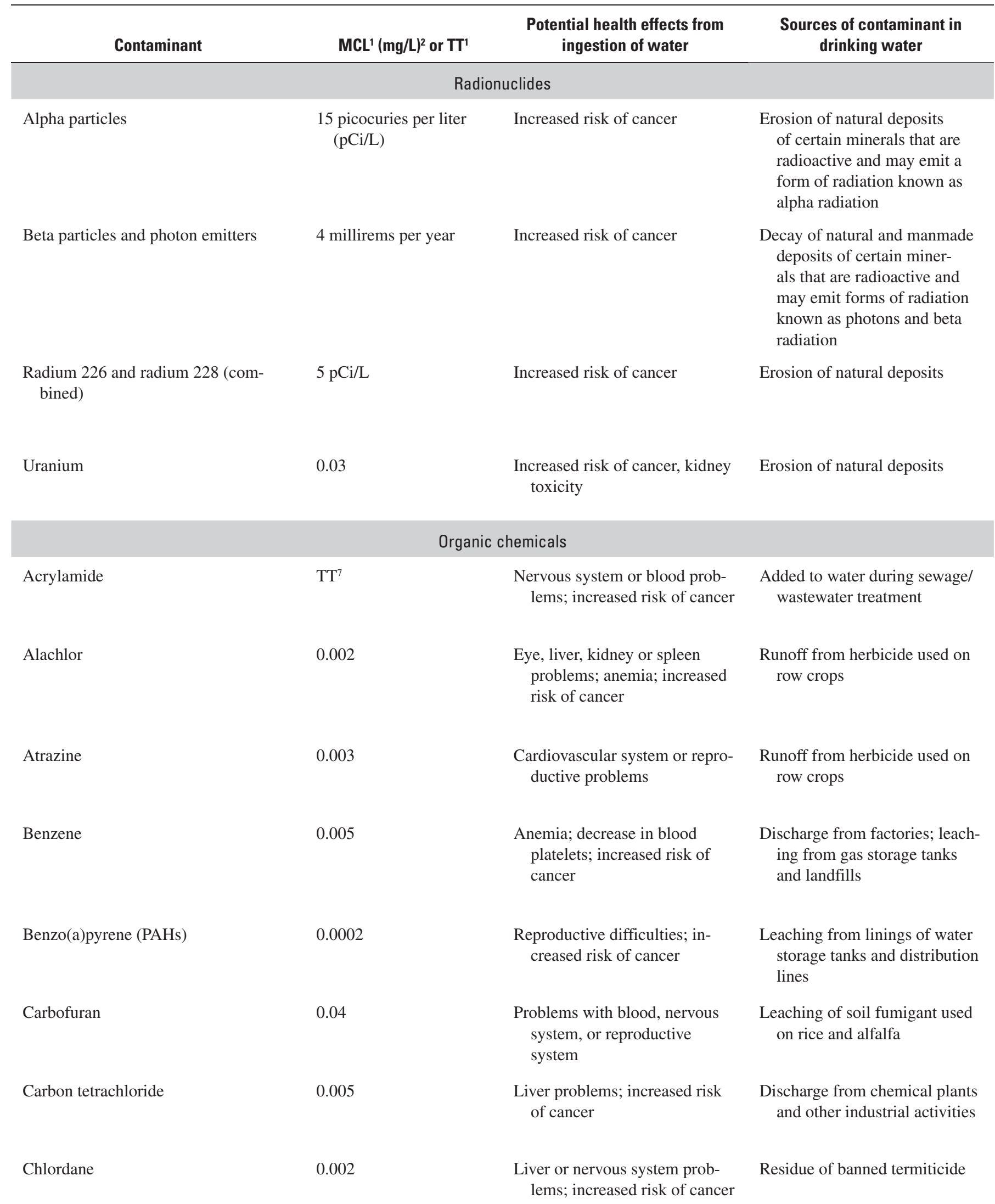




\section{Monitoring-Well Network and Sampling Design for Ground-Water Quality}

Appendix 2. U.S. Environmental Protection Agency Maximum Contaminant Levels (MCLs) for drinking water (from U.S. Environmental Protection Agency, 2004a).-Continued

\begin{tabular}{|c|c|c|c|}
\hline Contaminant & $\mathrm{MCL}^{1}\left(\mathrm{mg} / \mathrm{L}^{2}{ }^{2}\right.$ or TT${ }^{1}$ & $\begin{array}{l}\text { Potential health effects from } \\
\text { ingestion of water }\end{array}$ & $\begin{array}{l}\text { Sources of contaminant in } \\
\text { drinking water }\end{array}$ \\
\hline \multicolumn{4}{|c|}{ Organic chemicals-Continued } \\
\hline Chlorobenzene & 0.1 & Liver or kidney problems & $\begin{array}{l}\text { Discharge from chemical } \\
\text { and agricultural chemical } \\
\text { factories }\end{array}$ \\
\hline Dalapon & 0.2 & Minor kidney changes & $\begin{array}{l}\text { Runoff from herbicide used on } \\
\text { rights-of-way }\end{array}$ \\
\hline$o$-Dichlorobenzene & 0.6 & $\begin{array}{l}\text { Liver, kidney, or circulatory sys- } \\
\text { tem problems }\end{array}$ & $\begin{array}{l}\text { Discharge from industrial chem- } \\
\text { ical factories }\end{array}$ \\
\hline$p$-Dichlorobenzene & 0.075 & $\begin{array}{l}\text { Anemia; liver, kidney, or spleen } \\
\text { damage; changes in blood }\end{array}$ & $\begin{array}{l}\text { Discharge from industrial chem- } \\
\text { ical factories }\end{array}$ \\
\hline 1,2-Dichloroethane & 0.005 & Increased risk of cancer & $\begin{array}{l}\text { Discharge from industrial chem- } \\
\text { ical factories }\end{array}$ \\
\hline trans-1,2-Dichloroethylene & 0.1 & Liver problems & $\begin{array}{l}\text { Discharge from industrial chem- } \\
\text { ical factories }\end{array}$ \\
\hline Dichloromethane & 0.005 & $\begin{array}{l}\text { Liver problems; increased risk } \\
\text { of cancer }\end{array}$ & $\begin{array}{l}\text { Discharge from drug and } \\
\text { chemical factories }\end{array}$ \\
\hline 1,2-Dichloropropane & 0.005 & Increased risk of cancer & $\begin{array}{l}\text { Discharge from industrial chem- } \\
\text { ical factories }\end{array}$ \\
\hline Di(2-ethylhexyl) adipate & 0.4 & $\begin{array}{l}\text { Weight loss, liver problems, or } \\
\text { possible reproductive dif- } \\
\text { ficulties }\end{array}$ & $\begin{array}{l}\text { Discharge from chemical } \\
\text { factories }\end{array}$ \\
\hline
\end{tabular}


Appendix 2. U.S. Environmental Protection Agency Maximum Contaminant Levels (MCLs) for drinking water (from U.S. Environmental Protection Agency, 2004a).-Continued

\begin{tabular}{|c|c|c|c|}
\hline Contaminant & $\operatorname{MCL}^{1}(\mathrm{mg} / \mathrm{L})^{2}$ or $\mathrm{TT}^{1}$ & $\begin{array}{l}\text { Potential health effects from } \\
\text { ingestion of water }\end{array}$ & $\begin{array}{l}\text { Sources of contaminant in } \\
\text { drinking water }\end{array}$ \\
\hline \multicolumn{4}{|c|}{ Organic chemicals-Continued } \\
\hline Di(2-ethylhexyl) phthalate & 0.006 & $\begin{array}{l}\text { Reproductive difficulties; liver } \\
\text { problems; increased risk of } \\
\text { cancer }\end{array}$ & $\begin{array}{l}\text { Discharge from rubber and } \\
\text { chemical factories }\end{array}$ \\
\hline Dinoseb & 0.007 & Reproductive difficulties & $\begin{array}{l}\text { Runoff from herbicide used on } \\
\text { soybeans and vegetables }\end{array}$ \\
\hline Dioxin $(2,3,7,8-\mathrm{TCDD})$ & 0.00000003 & $\begin{array}{l}\text { Reproductive difficulties; in- } \\
\text { creased risk of cancer }\end{array}$ & $\begin{array}{l}\text { Emissions from waste incinera- } \\
\text { tion and other combustion; } \\
\text { discharge from chemical } \\
\text { factories }\end{array}$ \\
\hline Diquat & 0.02 & Cataracts & Runoff from herbicide use \\
\hline Endothall & 0.1 & $\begin{array}{l}\text { Stomach and intestinal prob- } \\
\text { lems }\end{array}$ & Runoff from herbicide use \\
\hline Endrin & 0.002 & Liver problems & Residue of banned insecticide \\
\hline Epichlorohydrin & $\mathrm{TT}^{7}$ & $\begin{array}{l}\text { Increased cancer risk, and over } \\
\text { a long period of time, stom- } \\
\text { ach problems }\end{array}$ & $\begin{array}{l}\text { Discharge from industrial } \\
\text { chemical factories; an impu- } \\
\text { rity of some water treatment } \\
\text { chemicals }\end{array}$ \\
\hline Ethylbenzene & 0.7 & Liver or kidneys problems & $\begin{array}{l}\text { Discharge from petroleum } \\
\text { refineries }\end{array}$ \\
\hline Ethylene dibromide & 0.00005 & $\begin{array}{l}\text { Problems with liver, stomach, } \\
\text { reproductive system, or kid- } \\
\text { neys; increased risk of cancer }\end{array}$ & $\begin{array}{l}\text { Discharge from petroleum } \\
\text { refineries }\end{array}$ \\
\hline Glyphosate & 0.7 & $\begin{array}{l}\text { Kidney problems; reproductive } \\
\text { difficulties }\end{array}$ & Runoff from herbicide use \\
\hline Heptachlor & 0.0004 & $\begin{array}{l}\text { Liver damage; increased risk of } \\
\text { cancer }\end{array}$ & Residue of banned termiticide \\
\hline Heptachlor epoxide & 0.0002 & $\begin{array}{l}\text { Liver damage; increased risk of } \\
\text { cancer }\end{array}$ & Breakdown of heptachlor \\
\hline Hexachlorobenzene & 0.001 & $\begin{array}{l}\text { Liver or kidney problems; } \\
\text { reproductive difficulties; } \\
\text { increased risk of cancer }\end{array}$ & $\begin{array}{l}\text { Discharge from metal refiner- } \\
\text { ies and agricultural chemical } \\
\text { factories }\end{array}$ \\
\hline Hexachlorocyclopentadiene & 0.05 & Kidney or stomach problems & $\begin{array}{l}\text { Discharge from chemical } \\
\text { factories }\end{array}$ \\
\hline
\end{tabular}


Appendix 2. U.S. Environmental Protection Agency Maximum Contaminant Levels (MCLs) for drinking water (from U.S. Environmental Protection Agency, 2004a).-Continued

\begin{tabular}{|c|c|c|c|}
\hline Contaminant & $\mathrm{MCL}^{1}(\mathrm{mg} / \mathrm{L})^{2}$ or TT${ }^{1}$ & $\begin{array}{l}\text { Potential health effects from } \\
\text { ingestion of water }\end{array}$ & $\begin{array}{l}\text { Sources of contaminant in } \\
\text { drinking water }\end{array}$ \\
\hline \multicolumn{4}{|c|}{ Organic chemicals-Continued } \\
\hline Lindane & 0.0002 & Liver or kidney problems & $\begin{array}{l}\text { Runoff/leaching from insecti- } \\
\text { cide used on cattle, lumber, } \\
\text { gardens }\end{array}$ \\
\hline Oxamyl (vydate) & 0.2 & Slight nervous system effects & $\begin{array}{l}\text { Runoff/leaching from insecti- } \\
\text { cide used on apples, potatoes, } \\
\text { and tomatoes }\end{array}$ \\
\hline Picloram & 0.5 & Liver problems & Herbicide runoff \\
\hline $\begin{array}{l}\text { Polychlorinated } \\
\text { biphenyls (PCBs) }\end{array}$ & 0.0005 & $\begin{array}{l}\text { Skin changes; thymus gland } \\
\text { problems; immune deficien- } \\
\text { cies; reproductive or nervous } \\
\text { system difficulties; increased } \\
\text { risk of cancer }\end{array}$ & $\begin{array}{l}\text { Runoff from landfills; discharge } \\
\text { of waste chemicals }\end{array}$ \\
\hline Toluene & 1 & $\begin{array}{l}\text { Nervous system, kidney, or liver } \\
\text { problems }\end{array}$ & $\begin{array}{l}\text { Discharge from petroleum } \\
\text { factories }\end{array}$ \\
\hline Toxaphene & 0.003 & $\begin{array}{l}\text { Kidney, liver, or thyroid prob- } \\
\text { lems; increased risk of cancer }\end{array}$ & $\begin{array}{l}\text { Runoff/leaching from insecti- } \\
\text { cide used on cotton and cattle }\end{array}$ \\
\hline 2,4,5-TP (Silvex) & 0.05 & Liver problems & Residue of banned herbicide \\
\hline 1,2,4-Trichlorobenzene & 0.07 & Changes in adrenal glands & $\begin{array}{l}\text { Discharge from textile finishing } \\
\text { factories }\end{array}$ \\
\hline
\end{tabular}


Appendix 2. U.S. Environmental Protection Agency Maximum Contaminant Levels (MCLs) for drinking water (from U.S. Environmental Protection Agency, 2004a).-Continued

\begin{tabular}{|c|c|c|c|}
\hline Contaminant & $\mathrm{MCL}^{1}(\mathrm{mg} / \mathrm{L})^{2}$ or $\mathrm{TT}^{1}$ & $\begin{array}{l}\text { Potential health effects from } \\
\text { ingestion of water }\end{array}$ & $\begin{array}{l}\text { Sources of contaminant in } \\
\text { drinking water }\end{array}$ \\
\hline \multicolumn{4}{|c|}{ Organic chemicals-Continued } \\
\hline 1,1,1-Trichloroethane & 0.2 & $\begin{array}{l}\text { Liver, nervous system, or circu- } \\
\text { latory problems }\end{array}$ & $\begin{array}{l}\text { Discharge from metal degreas- } \\
\text { ing sites and other factories }\end{array}$ \\
\hline 1,1,2-Trichloroethane & 0.005 & $\begin{array}{l}\text { Liver, kidney, or immune sys- } \\
\text { tem problems }\end{array}$ & $\begin{array}{l}\text { Discharge from industrial chem } \\
\text { ical factories }\end{array}$ \\
\hline Trichloroethylene & 0.005 & $\begin{array}{l}\text { Liver problems; increased risk } \\
\text { of cancer }\end{array}$ & $\begin{array}{l}\text { Discharge from metal degreas- } \\
\text { ing sites and other factories }\end{array}$ \\
\hline Vinyl chloride & 0.002 & Increased risk of cancer & $\begin{array}{l}\text { Leaching from PVC pipes; dis- } \\
\text { charge from plastic factories }\end{array}$ \\
\hline Xylenes (total) & 10 & Nervous system damage & $\begin{array}{l}\text { Discharge from petroleum } \\
\text { factories; discharge from } \\
\text { chemical factories }\end{array}$ \\
\hline \multicolumn{4}{|c|}{ Disinfectants } \\
\hline Chloramines $\left(\right.$ as $\left.\mathrm{Cl}_{2}\right)$ & $\mathrm{MRDL}^{1}=4.0$ & $\begin{array}{l}\text { Eye/nose irritation; stomach } \\
\text { discomfort, anemia }\end{array}$ & $\begin{array}{l}\text { Water additive used to control } \\
\text { microbes }\end{array}$ \\
\hline Chlorine (as $\mathrm{Cl}_{2}$ ) & $\mathrm{MRDL}^{1}=4.0$ & $\begin{array}{l}\text { Eye/nose irritation; stomach } \\
\text { discomfort }\end{array}$ & $\begin{array}{l}\text { Water additive used to control } \\
\text { microbes }\end{array}$ \\
\hline Chlorine dioxide (as $\mathrm{ClO}_{2}$ ) & $\mathrm{MRDL}^{1}=0.8$ & $\begin{array}{l}\text { Anemia; infants \& young chil- } \\
\text { dren: nervous system effects }\end{array}$ & $\begin{array}{l}\text { Water additive used to control } \\
\text { microbes }\end{array}$ \\
\hline \multicolumn{4}{|c|}{ Disinfection by-products } \\
\hline Bromate & 0.010 & Increased risk of cancer & $\begin{array}{l}\text { By-product of drinking water } \\
\text { disinfection }\end{array}$ \\
\hline Chlorite & 1.0 & $\begin{array}{l}\text { Anemia; nervous system effects } \\
\text { in infants and young children }\end{array}$ & $\begin{array}{l}\text { By-product of drinking water } \\
\text { disinfection }\end{array}$ \\
\hline Haloacetic acids & 0.060 & Increased risk of cancer & $\begin{array}{l}\text { By-product of drinking water } \\
\text { disinfection }\end{array}$ \\
\hline Total trihalomethanes & 0.080 & $\begin{array}{l}\text { Liver, kidney, or central nervous } \\
\text { system problems; increased } \\
\text { risk of cancer }\end{array}$ & $\begin{array}{l}\text { By-product of drinking water } \\
\text { disinfection }\end{array}$ \\
\hline
\end{tabular}


Appendix 2. U.S. Environmental Protection Agency Maximum Contaminant Levels (MCLs) for drinking water (from U.S. Environmental Protection Agency, 2004a).-Continued

\begin{tabular}{|c|c|c|c|}
\hline Contaminant & $\mathrm{MCL}^{1}(\mathrm{mg} / \mathrm{L})^{2}$ or TT${ }^{1}$ & $\begin{array}{l}\text { Potential health effects from } \\
\text { ingestion of water }\end{array}$ & $\begin{array}{l}\text { Sources of contaminant in } \\
\text { drinking water }\end{array}$ \\
\hline \multicolumn{4}{|c|}{ Microorganisms } \\
\hline Cryptosporidium & $\mathrm{TT}^{3}$ & $\begin{array}{l}\text { Gastrointestinal illness (such as } \\
\text { diarrhea, vomiting, cramps) }\end{array}$ & Human and fecal animal waste \\
\hline Heterotrophic plate count (HPC) & $\mathrm{TT}^{3}$ & $\begin{array}{l}\text { HPC has no health effects; it is } \\
\text { an analytic method used to } \\
\text { measure the variety of bacte- } \\
\text { ria that are common in water. } \\
\text { The lower the concentration } \\
\text { of bacteria in drinking water, } \\
\text { the better maintained the } \\
\text { water system is. }\end{array}$ & $\begin{array}{l}\text { HPC measures a range of bacte- } \\
\text { ria that are naturally present } \\
\text { in the environment }\end{array}$ \\
\hline Legionella & $\mathrm{TT}^{3}$ & $\begin{array}{l}\text { Legionnaire's Disease, a type of } \\
\text { pneumonia }\end{array}$ & $\begin{array}{l}\text { Found naturally in water; multi- } \\
\text { plies in heating systems }\end{array}$ \\
\hline $\begin{array}{l}\text { Total coliforms (including fecal coli- } \\
\text { form and } E \text {. coli) }\end{array}$ & 5.0 percent $^{4}$ & $\begin{array}{l}\text { Not a health threat in itself; it } \\
\text { is used to indicate whether } \\
\text { other potentially harmful } \\
\text { bacteria may be present }\end{array}$ & $\begin{array}{l}\text { Coliforms are naturally present } \\
\text { in the environment as well as } \\
\text { in feces; fecal coliforms and } \\
\text { E. coli only come from hu- } \\
\text { man and animal fecal waste }\end{array}$ \\
\hline Viruses (enteric) & $\mathrm{TT}^{3}$ & $\begin{array}{l}\text { Gastrointestinal illness (such as } \\
\text { diarrhea, vomiting, cramps) }\end{array}$ & Human and animal fecal waste \\
\hline
\end{tabular}




\section{Notes}

${ }^{1}$ Definitions:

Maximum Contaminant Level (MCL) — The highest level of a contaminant that is allowed in drinking water. MCLs are set as close to Maximum Contaminant Level Goals as feasible using the best available treatment technology and taking cost into consideration. MCLs are enforceable standards.

Maximum Residual Disinfectant Level (MRDL) - The highest level of a disinfectant allowed in drinking water. There is convincing evidence that addition of a disinfectant is necessary for control of microbial contaminants.

Treatment Technique (TT) — A required process intended to reduce the level of a contaminant in drinking water.

Million Fibers Per Liter (MFL) - A measure of the presence of asbestos fibers that are longer than 10 micrometers.

${ }^{2}$ Units are in milligrams per liter $(\mathrm{mg} / \mathrm{L})$ unless otherwise noted. Milligrams per liter are equivalent to parts per million.

${ }^{3}$ USEPA's surface-water treatment rules require systems using surface water or ground water under the direct influence (GWUDI) of surface water to (1) disinfect their water, and (2) filter their water or meet criteria for avoiding filtration so that the following contaminants are controlled at the following levels:

- Cryptosporidium (as of January 1, 2002 for systems serving 10,000 or more people, and January 14, 2005 for systems serving fewer than 10,000 people): 99 percent removal.

- Giardia lamblia: 99.9 percent removal/inactivation

- Viruses: 99.99 percent removal/inactivation

- Legionella: No limit, but USEPA believes that if Giardia and viruses are removed/inactivated, Legionella will also be controlled.

- Turbidity: At no time can turbidity (cloudiness of water) go above 5 nephelometric turbidity units (NTU); systems that filter must ensure that the turbidity goes no higher than 1 NTU (0.5 NTU for conventional or direct filtration) in at least 95 percent of the daily samples in any month. As of January 1, 2002, turbidity may never exceed 1 NTU, and must not exceed $0.3 \mathrm{NTU}$ in 95 percent of daily samples in any month.

- HPC (Heterotrophic plate count): No more than 500 bacterial colonies per milliliter. (Heterotrophic plate count is a procedure for estimating the number of live heterotrophic bacteria in water).
- Long Term 1 Enhanced Surface Water Treatment (Effective Date: January 14, 2005); Surface-water systems or GWUDI systems serving fewer than 10,000 people must comply with the applicable Long Term 1 Enhanced Surface Water Treatment Rule provisions (for example, turbidity standards, individual filter monitoring, Cryptosporidium removal requirements, updated watershed control requirements for unfiltered systems).

- Filter Backwash Recycling; The Filter Backwash Recycling Rule requires systems that recycle to return specific recycle flows through all processes of the system's existing conventional or direct filtration system or at an alternate location approved by the State.

${ }^{4}$ No more than 5.0 percent of samples with positive total coliform in a month. (For water systems that collect fewer than 40 routine samples per month, no more than one sample can be total coliform-positive per month.)

${ }^{5}$ Fecal coliform and E. coli are bacteria whose presence indicates that the water may be contaminated with human or animal wastes. Disease-causing microbes (pathogens) in these wastes can cause diarrhea, cramps, nausea, headaches, or other symptoms. These pathogens may pose a special health risk for infants, young children, and people with severely compromised immune systems.

${ }^{6}$ Lead and copper are regulated by a Treatment Technique that requires systems to control the corrosiveness of their water. If more than 10 percent of tap-water samples exceed the Action Level, water systems must take additional steps. The Action Level is $1.3 \mathrm{mg} / \mathrm{L}$ for copper and $0.015 \mathrm{mg} / \mathrm{L}$ for lead.

${ }^{7}$ Each water system must certify, in writing, to the state (using third-party or manufacturer's certification) that when acrylamide and epichlorohydrin are used in drinking water systems, the combination (or product) of dose and monomer level does not exceed the levels specified, as follows:

- Acrylamide $=0.05$ percent dosed at $1 \mathrm{mg} / \mathrm{L}$ (or equivalent)

- Epichlorohydrin = 0.01 percent dosed at $20 \mathrm{mg} / \mathrm{L}$ (or equivalent) 


\section{$38 \quad$ Monitoring-Well Network and Sampling Design for Ground-Water Quality}

Appendix 3. U.S. Environmental Protection Agency Secondary Maximum Contaminant Levels (SMCLs) for drinking water (from U.S. Environmental Protection Agency, 2004a).

[mg/L, milligrams per liter]

\begin{tabular}{|c|c|c|c|}
\hline Contaminant & SMCL & Contaminant & SMCL \\
\hline Aluminum & 0.05 to $0.2 \mathrm{mg} / \mathrm{L}$ & Manganese & $0.05 \mathrm{mg} / \mathrm{L}$ \\
\hline Chloride & $250 \mathrm{mg} / \mathrm{L}$ & Odor & 3 threshold odor number \\
\hline Color & 15 (color units) & $\mathrm{pH}$ & 6.5-8.5 standard units \\
\hline Copper & $1.0 \mathrm{mg} / \mathrm{L}$ & Silver & $0.10 \mathrm{mg} / \mathrm{L}$ \\
\hline $\begin{array}{l}\text { Corrosivity } \\
\text { Fluoride }\end{array}$ & $\begin{array}{l}\text { noncorrosive } \\
2.0 \mathrm{mg} / \mathrm{L}\end{array}$ & Sulfate & $250 \mathrm{mg} / \mathrm{L}$ \\
\hline Foaming agents & $0.5 \mathrm{mg} / \mathrm{L}$ & Total dissolved solids & $500 \mathrm{mg} / \mathrm{L}$ \\
\hline Iron & $0.3 \mathrm{mg} / \mathrm{L}$ & Zinc & $5 \mathrm{mg} / \mathrm{L}$ \\
\hline
\end{tabular}

Appendix 4. State of Wyoming ground-water-quality standards.

[Concentrations are in milligrams per liter except as otherwise indicated; s.u., standard units; pCi/L, picocuries per liter; meq/L, milliequivalents per liter; ,-- none]

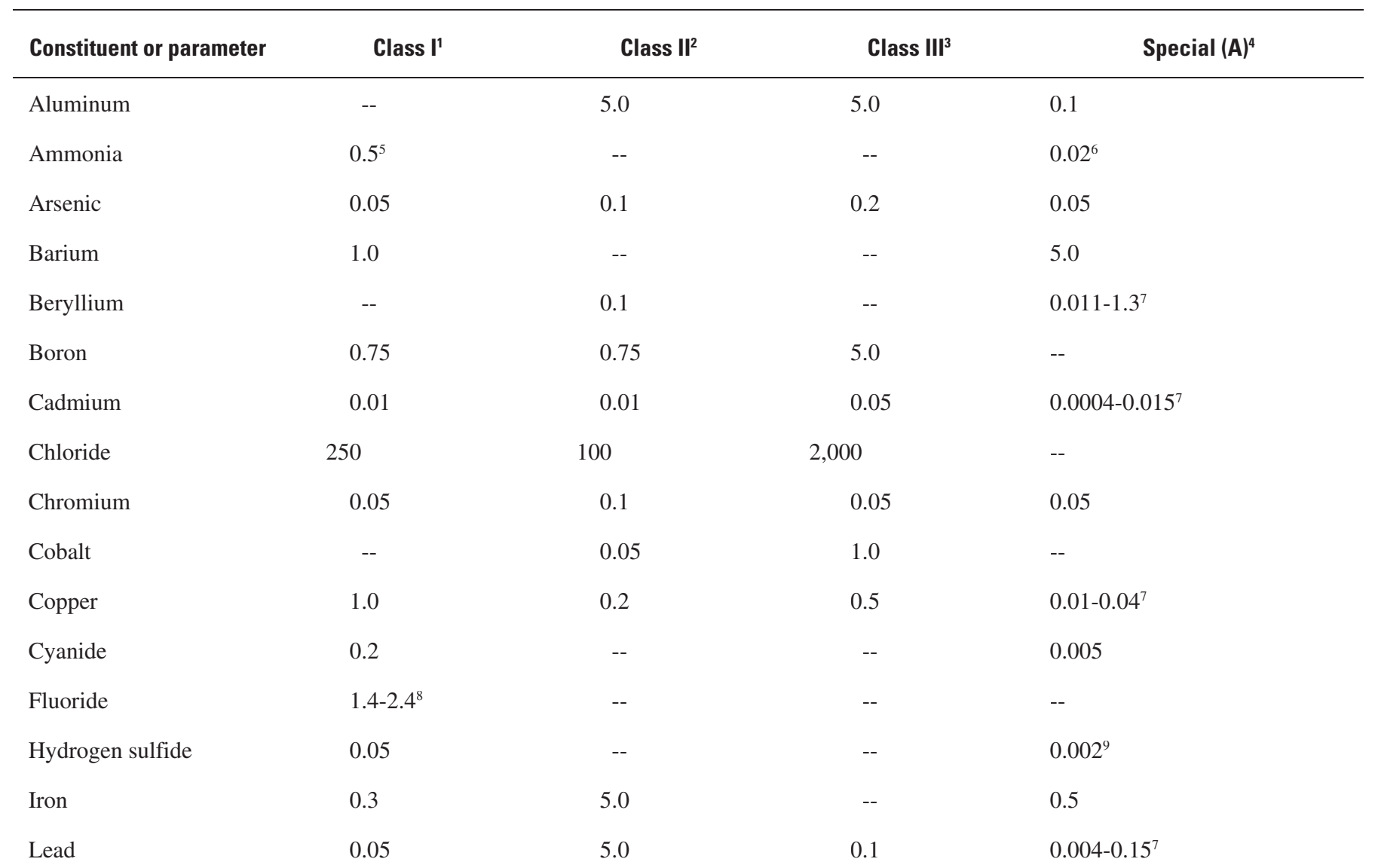


Appendix 4. State of Wyoming ground-water-quality standards.-Continued

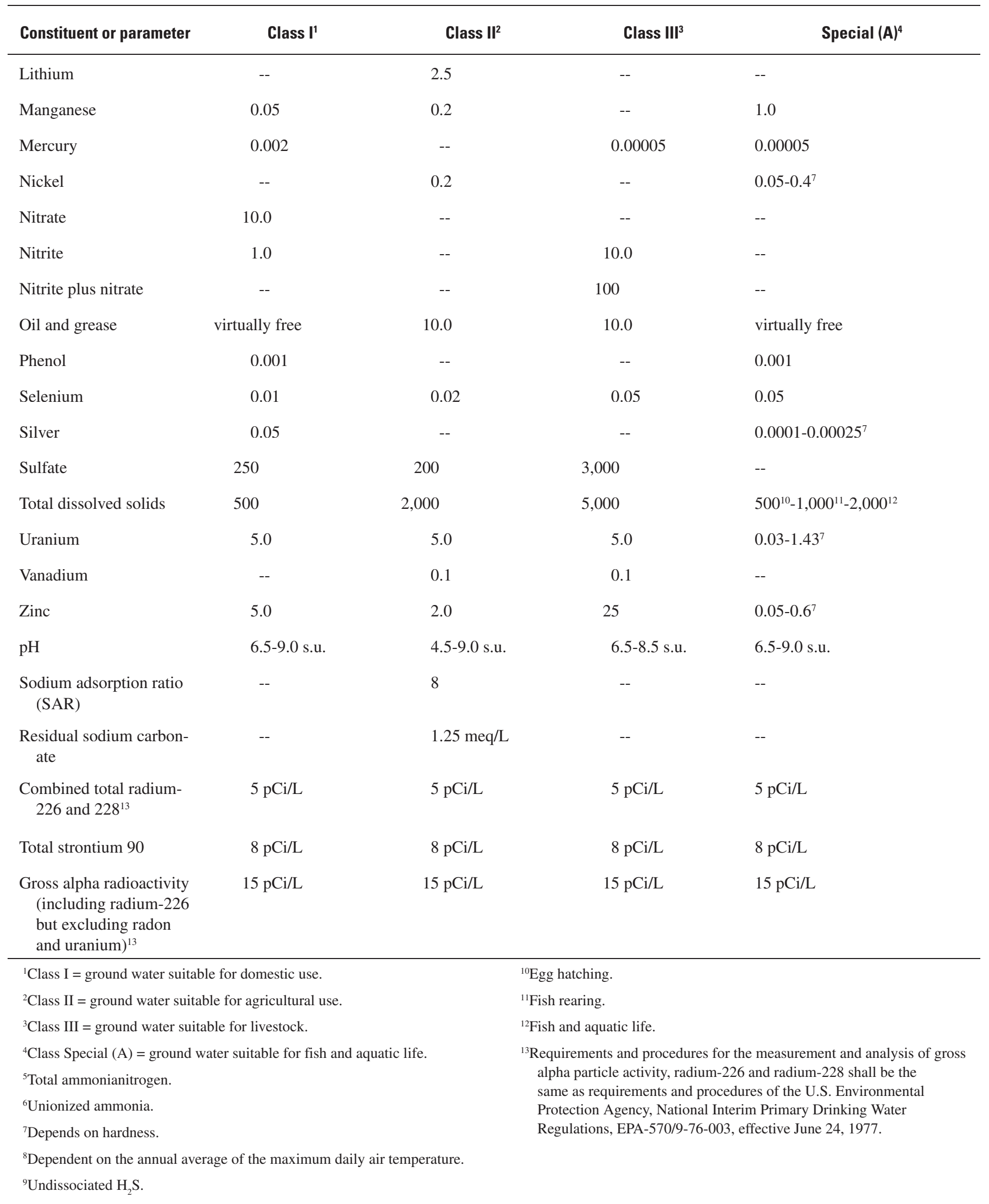



For more information concerning the research in this report, contact:

District Chief

U.S. Geological Survey

2617 E. Lincolnway, Suite B

Cheyenne, Wyoming 82001-5662 


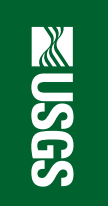

